\title{
Review \\ A Review of Breast Cancer Risk Factors in Adolescents and Young Adults
}

\author{
Una Mary McVeigh ${ }^{1}$, John William Tepper ${ }^{2}$ and Terri Patricia McVeigh ${ }^{3,4, *(D)}$ \\ 1 School of Medicine, National University of Ireland Galway, H91 TK33 Galway, Ireland; \\ u.mcveigh1@nuigalway.ie \\ 2 Department of Internal Medicine/Pediatrics, Indiana University School of Medicine, \\ Indianapolis, IN 46202-3082, USA; jwtepper@iu.edu \\ 3 Royal Marsden NHS Foundation Trust, London SW3 6JJ, UK \\ 4 Institute of Cancer Research, London SW7 3RP, UK \\ * Correspondence: terri.mcveigh@nhs.net
}

Citation: McVeigh, U.M.; Tepper, J.W.; McVeigh, T.P. A Review of Breast Cancer Risk Factors in Adolescents and Young Adults. Cancers 2021, 13, 5552. https://doi.org/10.3390/ cancers13215552

Academic Editor:

Kyriaki Michailidou

Received: 1 October 2021

Accepted: 3 November 2021

Published: 5 November 2021

Publisher's Note: MDPI stays neutral with regard to jurisdictional claims in published maps and institutional affiliations.

Copyright: () 2021 by the authors. Licensee MDPI, Basel, Switzerland. This article is an open access article distributed under the terms and conditions of the Creative Commons Attribution (CC BY) license (https:// creativecommons.org/licenses/by/ $4.0 /)$.
Simple Summary: Cancer diagnosed in patients between the ages of 15 and 39 deserves special consideration. Diagnoses within this cohort of adolescents and young adults include childhood cancers which present at an older age than expected, or an early presentation of cancers that are typically observed in older adults, such as breast cancer. Cancers within this age group are associated with worse disease-free and overall survival rates, and the incidence of these cases are rising. Knowing an individual's susceptibility to disease can change their clinical management and allow for the risk-testing of relatives. This review discusses the risk factors that contribute to breast cancer in this unique cohort of patients, including inherited genetic risk factors, as well as environmental and lifestyle factors. We also describe risk models that allow clinicians to quantify a patient's lifetime risk of developing disease.

Abstract: Cancer in adolescents and young adults (AYAs) deserves special consideration for several reasons. AYA cancers encompass paediatric malignancies that present at an older age than expected, or early-onset of cancers that are typically observed in adults. However, disease diagnosed in the AYA population is distinct to those same cancers which are diagnosed in a paediatric or older adult setting. Worse disease-free and overall survival outcomes are observed in the AYA setting, and the incidence of AYA cancers is increasing. Knowledge of an individual's underlying cancer predisposition can influence their clinical care and may facilitate early tumour surveillance strategies and cascade testing of at-risk relatives. This information can further influence reproductive decision making. In this review we discuss the risk factors contributing to AYA breast cancer, such as heritable predisposition, environmental, and lifestyle factors. We also describe a number of risk models which incorporate genetic factors that aid clinicians in quantifying an individual's lifetime risk of disease.

Keywords: breast cancer; AYA cancer; risk prediction; inherited risk

\section{Cancer in Adolescents and Young Adults}

Adolescents and young adults (AYAs) with cancer, who are defined as those individuals diagnosed with cancer between the ages of 15 and 39 [1], deserve special consideration for a number of reasons. Cancers in this cohort may include those more typically identified in older adults that occur at unexpectedly young ages, or, conversely, more typically paediatric cancers that are diagnosed later in life. The most common types of cancers diagnosed in this population include breast, cervical, and thyroid cancers, along with melanoma, haematological malignancies, and central nervous system tumours [2,3]. The incidence of cancer diagnoses in AYAs has increased significantly since 2000 [4]. There are several indicators that the diseases that are diagnosed in the AYA population is distinct to those same cancers diagnosed in a paediatric or older adult setting. Disease-free and 
overall survival outcomes in the AYA setting are worse, and differences in the biology and epidemiology of these tumours have been observed [1,5-7]. There is evidence that AYA patients present with a more aggressive disease and use mastectomy and chemotherapy at higher rates than adult breast cancer patients [8-12]. Furthermore, AYAs have additional complicating factors related to fertility preservation and family planning, as well as psychosocial implications. There is an associated financial impact, with an associated loss of earnings related to time off work, as well as treatment-related costs.

Underlying hereditary cancer susceptibility syndromes account for $7-10 \%$ of cancer diagnoses in children and adolescents [13-16]. For young adults, moderate- to high-risk cancer susceptibility variants have been associated with $5.9-23 \%$ of early-onset cancers, including invasive breast cancer [17-23]. Knowledge of an affected patient's underlying high-risk genotype can influence clinical care in terms of surgical and chemotherapeutic decision-making, as well as their future cancer risk estimation, while in the unaffected individual, early intervention with regular screening, as well as chemo- and/or surgical prophylaxis may minimise cancer risk, or at least facilitate early diagnosis and treatment. In AYAs, identifying a monogenic risk factor for cancer may also influence reproductive decision making, and may facilitate options such as pre-implantation genetic diagnosis, or non-invasive/invasive prenatal testing.

\section{Epidemiology and Aetiology of Breast Cancer}

Breast cancer among cis-gender females is very common, affecting approximately 1 in 8 women over their lifetime, with the peak age-specific incidence between the ages of 65 and 69 (417.3 per 100,000), when compared to an incidence of 109.2 per 100,000 in those aged under 40 [2]. Female breast cancer diagnosis before age 30 is particularly rare (incidence rate 12.2/100,000). Male (cis-male) breast cancer is rare at any age, with an overall incidence of 1.3 per 100,000; however, cases before age 40 are particularly infrequent [2].

The risk of breast cancer is dependent on several so-called modifiable factors, which include body weight, use of hormone replacement therapy, and reproductive factors, as well as non-modifiable factors such as age at menarche and menopause, breast density, and a family history of breast cancer. Twin studies demonstrated that $30 \%$ of breast cancers are attributed to hereditary factors [24]. Breast cancer incidence is twice as high in women with at least one affected first-degree relative [25]. There is an observable Mendelian inheritance pattern in 5-10\% of all breast cancers, in which case the cancer risk is considered a hereditary trait [26]. A further $20 \%$ of all breast cancers are considered "familial", where familial clustering of affected first- or second-degree relatives is observed in the absence of an obvious monogenic variant [27].

Research over the past three decades has identified germline variants at numerous loci with variable associated disease penetrance. The genetic variants that predispose a person to breast cancer are now broadly categorised into three groups: high-, moderate-, and low-risk variants, depending on the relative risk conferred by the variant. Pathogenic high-risk variants in several genes are associated with a greater than four-fold risk of breast cancer than that observed in the general population [28], and moderate-risk in the order of 2-4 times greater than population risk [29-32].

In keeping with the rules governing biological fitness, it follows that those variants that are associated with a particularly high risk of early-onset disease are usually rare in the general population when compared to low-risk susceptibility alleles, which may be relatively common [33]. Risk alleles are not mutually exclusive, and other environmental or lifestyle risk factors can modify the absolute risk of disease associated with a genetic trait, such that a carrier of a so-called "moderate-risk" variant allele may have an overall high risk, when a holistic risk assessment is undertaken.

\section{Monogenic Predisposition to Breast Cancer}

Individuals who carry inherited genetic traits that are associated with a high risk of cancer can manage their cancer risk through a combination of surveillance, risk-reducing 
surgery or other techniques. The exact advice provided to carriers of such traits will depend on the genotype, associated cancer risk and the availability of proven screening or other risk-reducing interventions. The early recognition of a genetic predisposition to disease, as well as the potential barriers to genetic testing where such a predisposition is suspected, is crucial to facilitate cascade testing and early intervention in at-risk relatives [34].

\subsection{TP53}

TP53 encodes for the p53 protein, which is commonly referred to as the "guardian of the genome" [35]. In response to cellular stress, DNA damage, and oncogene activation, p53 regulates the expression of thousands of other genes to induce DNA repair, cell cycle arrest, apoptosis, or senescence. Pathogenic variants in TP53 may cause conformational changes in the protein, abrogate DNA binding or suppress interaction with target genes. Deleterious variants may cause a partial or total loss of key functions, and certain deleterious variants may lead to an inappropriate gain of function-such as inappropriate transcriptional activity [35]. Germline variants in certain tumour suppressor genes follow the two-hit hypothesis [36], behaving recessively at the cellular level, such that loss of function is not apparent until a second somatic hit (deletion, variation or silencing by methylation) occurs in the normal allele-leading to a demonstrable loss of heterozygosity. In contrast, this may not necessarily be evident in the case of TP53 - certain TP53 variants may exert dominant negative effects on the wild type allele, for example, by inactivation of the wild-type protein or through dimerization [37].

Disruption of p53 function due to germline or somatic pathogenic variants contributes to virtually all of the hallmark features of cancer [35]. Somatic TP53 variants are common across a host of cancer types, most commonly colorectal and head and neck cancer, and TP53-mutant cancers demonstrate higher rates of chemo- and or radio-therapeutic resistance, increased risk of relapse, and reduced survival [38,39].

Heterozygous pathogenic germline variants of TP53 give rise to heritable TP53-related cancer (hTP53rc) syndrome, of which the most extreme phenotype is traditionally referred to as Li Fraumeni syndrome (LFS) [40]. This rare syndrome predisposes affected individuals to a wide range of malignancies, including sarcoma of the soft tissue and bone, brain tumours, haematological malignancies, adrenocortical cancer, and breast cancer, among others, with this cancer risk starting from early childhood [40].

Most pathogenic TP53 variants are associated with a higher penetrance than $B R C A$ variants [41-43], although variants with a reduced penetrance have been reported. The median age of a diagnosis of breast cancer, in a female carrier of a germline pathogenic variant in TP53, is 33 years of age, with approximately one third of this population diagnosed prior to the age of 30 years. Indeed, overall, approximately $50 \%$ of the cancers occurring in the carriers of such variants occur before this age. The population frequency of germline pathogenic variants in TP53 is very low, ranging from 1 in 3555 to 1 in 5476 individuals [44], although the prevalence is higher in certain populations where founder events have been reported [45]. In women diagnosed with breast cancer before age 30, the likelihood of detecting an underlying germline TP53 variant is $2-8 \%$ [46]. The likelihood of detecting such variants in women with breast cancer decreases with age, although certain variants have been reported to be associated with a later age of diagnosis [47]. The likelihood of identifying an underlying germline TP53 variant is also dependent on the molecular phenotype of the tumour. There is an apparent enrichment for HER2-overexpression, and particularly "triple positive" (ER+, PR+ and HER2+) breast cancers - compared to the general population, in which HER2-overexpressing breast cancers account for $20-30 \%$ of cases, 63-83\% of breast cancers in carriers of pathogenic TP53 variants are HER2-amplified [48,49]. Interestingly, the risk of male breast cancer does not appear to be significantly increased [40]. Malignant Phyllodes tumours have also been reported in this population [41].

Given the risk of early-onset cancer, it is advised that carriers of pathogenic TP53 variants have an annual clinical screening and a whole-body MRI (WBMRI), with an annual 
breast MRI beginning at 20 years of age [40]. A discussion regarding prophylactic risk reducing surgery may be appropriate [50].

\subsection{BRCA1 and BRCA2}

Since their discovery over three decades ago, the breast cancer 1 (BRCA1) and 2 (BRCA2) genes remain the most clinically significant breast cancer predisposition genes. A multi-functional protein, BRCA1 is involved in a wide array of cellular pathways, including DNA damage repair (DDR), chromatin remodelling, gene expression, and protein ubiquitination [51-54]. BRCA2 is also involved in DDR, primarily as part of the homologous repair pathway (HRR) [55,56].

Heterozygous carriers of germline pathogenic variants in either $B R C A 1$ or $B R C A 2$ are at significantly increased lifetime risk of breast and other cancers, with risk accruing from a young age. It is estimated that between 1 in 300 and 1 in 200 individuals in the general population carry a germline pathogenic variant in one of these genes [57-59]. There are recurrent founder events in these genes; approximately 1 in 40 individuals of Ashkenazi Jewish heritage will carry a germline pathogenic variant in either $B R C A 1$ or $B R C A 2$, and most of these identified variants will be one of three founder mutations [60]. In women with breast cancer, the prevalence of pathogenic $B R C A 1 / B R C A 2$ variants is approximately 1 in 33 [58], and almost 1 in 8 if the affected individual is an AYA [17,58,61].

The cumulative lifetime risk of breast cancer that is conferred by pathogenic $B R C A 1$ and $B R C A 2$ variants is estimated to be $65-79 \%$ and $61-77 \%$, respectively [62]. There is evidence to suggest that the cancers occurring in the carriers of germline $B R C A$ variants result in more aggressive malignancies at earlier ages. The cancer risk associated with pathogenic BRCA1 variants peaks between 30 and 50 years [63], with a standardised incidence rate of $46.2(37.3-57.1) \%$ between the ages of 31 and 40 years compared to 7 $(4.5-11) \%$ in those between 61 and 70 years [62]. The majority of breast cancers in patients who carry a germline $B R C A 1$ variant are the basal subtype of triple negative breast cancer (TNBC) [64-66]. There is some evidence that $B R C A 2$ variants show more association with the Luminal B subtype, and a higher risk of contralateral disease, but no definitive association has been demonstrated thus far [66-68]. Germline BRCA variants are associated with more aggressive malignancies at earlier ages, presenting with a higher grade and metastatic potential. Tumours that are associated with a germline variant are also associated with a poorer prognosis than those that acquire a somatic BRCA variant [69].

The risk of male breast cancer is also increased in the male carriers of such variants, particularly those in $B R C A 2$, where the lifetime risk is approximately $8-10 \%$ when compared to $B R C A 1$, where the risk is in the order of $1 \%$ [70]. The risk of prostate cancer is also particularly increased in the male carriers of $B R C A 2$ variants, with a lifetime risk of approximately $25-30 \%$, and a tendency to a more aggressive phenotype. The risk of prostate cancer in male carriers of $B R C A 1$ variants is approximately equivalent to the general population's risk, but the phenotype of such cancers, as well as the therapeutic approach, is similar to that of carriers of $B R C A 2$ variants. Female carriers of BRCA1/BRCA2 variants also have the additional high risk of ovarian cancer, with the cumulative lifetime risk in carriers of $B R C A 1$ being $44 \%$ (36-53\%), compared to $B R C A 2$, which is $17 \%$ (11-25\%) [62]. Both female and male carriers have increased risks of pancreatic cancer [71], and there is also an increased risk of melanoma-type skin cancer in carriers of $B R C A 2$ variants [72].

In unaffected women found to carry pathogenic/likely pathogenic variants in $B R C A 1$ or $B R C A 2$, high intensity surveillance with MRIs and/or mammograms (depending on age and breast density) is recommended, starting from 25-30 years depending on family history and local guidelines [73,74]. The carriers of such variants may wish to consider surgical prophylaxis, although the survival benefit of this when compared to regular surveillance is uncertain; any potential benefit diminishes rapidly with increasing age at surgical intervention [75-77]. Carriers of $B R C A$ variants who have already developed breast cancer are also predisposed to developing further primary breast cancers in any residual breast tissue. Consequently, affected patients may choose to have contralateral 
prophylactic surgery during or after therapeutic surgery, although several factors influence the potential survival benefit of this approach, including age and the stage of the first breast cancer, systemic treatments, age at prophylactic surgery, and surveillance [78]. The benefit of risk-reducing mastectomy after a diagnosis of ovarian cancer is uncertain, and the life expectancy of a patient with BRCA-associated ovarian cancer may be too short to warrant preventive surgery. However, such surgery may be considered in individuals with occult, or stage I/II ovarian cancer, which is diagnosed before age 55, with at least 10 years of disease-free survival [79].

As well as contributing significantly to the risk of disease, BRCA-deficiency modulates the response of disease to systemic cancer treatment. Loss of BRCA1 or BRCA2 function, as a consequence of biallelic variation or hypermethylation (germline and/or somatic), leads to homologous recombination repair deficiency, which can then be exploited for therapeutic purposes. Such a deficiency is characterised by a unique mutational signature, and a high genomic instability score (GIS), which is derived from an algorithmic measurement of largescale state transitions, telomeric allelic imbalance, and loss of heterozygosity [80]. Tumours in $B R C A$ variant carriers demonstrate a higher objective response rate to platinum-based chemotherapy (carboplatin) versus taxane chemotherapy (docetaxel) (68\% vs. 33\%) [81]. High rates of pathological complete remission have also been demonstrated in BRCA1 variant carriers who are treated with platinum-based neoadjuvant chemotherapy [82]. These data highlight the importance of $B R C A$ variant screening in patients with TNBC. However, it has been reported that secondary tumours develop resistance to platinumbased therapies via a somatic reversion mutation which restores BRCA function [83]. This same mechanism could result in resistance to another therapeutic option: PARP-inhibitors.

The use of PARPi in BRCA-deficient tumours has been shown to be particularly effective [84-86]. In the carriers of germline pathogenic variants in BRCA1 or BRCA2, olaparib treatment has been shown to lead to superior progression-free survival when compared to standard therapy in individuals with HER2-negative metastatic breast cancer [87], and to longer disease-free survival in individuals with high-risk HER2-negative early breast cancer when compared to placebo [88]. The efficacy of PARP inhibitors in the therapeutic context has prompted much interest in their potential application in chemoprophylaxis. PARP inhibitors have been shown to delay mammary tumour development in BRCAdeficient murine models $[89,90]$. Further research is required to determine their efficacy in the delay or prevention of cancer onset in the carriers of germline $B R C A 1 / B R C A 2$ variants, as well as to investigate their potential toxicity, risk of secondary cancer development and any mechanisms of resistance [91,92]. In the UK, for chemoprevention in unaffected women with a moderate $(17-30 \%)$ or high $(>30 \%)$ risk of breast cancer, the National Institute for Health and Care Excellence has recommended the consideration of tamoxifen, raloxifene or anastrozole, depending on menopausal status, the presence of a uterus, and history of contra-indications such as osteoporosis, endometrial cancer or thrombo-embolic disease [74]. Given their roles as selective oestrogen receptor modulators and aromatase inhibitors, the impact on breast cancer risk reduction is largely limited to oestrogen receptor-positive cancers [93]. Their utility in the carriers of pathogenic BRCA1 variants is therefore limited, considering their strong association with ER-negative disease [94]. Other agents, including denosumab and metformin have also been investigated as chemoprophylactics [95].

Ovarian cancer screening in individuals with germline variants in BRCA1 or BRCA2 is contentious. Annual screening with CA-125 and transvaginal ultrasound has a high sensitivity and positive predictive value, but the majority of cancers detected in this manner are stage III or higher, and an annual screening is interval associated with a poor overall 10-year survival in the carriers of germline BRCA1/BRCA2 variants [96]. The United Kingdom Collaborative Trial of Ovarian Cancer Screening (UKCTOCS) investigated the role of multimodal screening, with the use of serial CA-125 measurements (in the context of Risk of Ovarian Cancer Algorithm, ROCA), and second-line transvaginal ultrasound (TVUS) [97]. This study demonstrated a stage shift but did not provide conclusive evidence 
of survival benefit. At present, the only proven way to minimise the risk of ovarian cancer in the carriers of pathogenic variants in $B R C A 1 / B R C A 2$ is prophylactic bilateral salpingooophorectomy. The optimum age at which this is undertaken should consider age-related penetrance, and the adverse impact of premature menopause on heart, brain and bone health. Risk-reducing salpingo-oophorectomy is associated with a $96 \%$ reduction in the risk of tubo-ovarian cancer; and may be associated with a reduction in breast cancer risk in the carriers of $B R C A 2$, but not $B R C A 1$, variants [98,99].

\subsection{PALB2}

The tumour suppressor PALB2 mediates the physical interaction of BRCA2 with the COOH-terminal fragment of BRCA1 [100]. Heterozygous pathogenic germline variants in PALB2 have been associated with an increased risk of breast cancer which approaches that seen with variants in $B R C A 2$, in the order of $48-63 \%$, with increased risks for those patients with a family history of breast cancer [101-105]. The risks associated with germline pathogenic variants in PALB2 are highest for those under 40 years of age, at 8-9 times the risk of the general population, and while this falls somewhat with age, this risk remains significant, with a 5-fold relative risk in those carriers aged over 60 years [102,105]. Male breast cancers have been reported in the carriers of PALB2 variants, but the absolute risk appears very low $0.9(0.2-5) \%$. Additionally, female carriers of PALB2 variants have increased risks of ovarian cancer in the order of $5(2-10) \%$, and carriers of either gender have an increased risk of pancreatic cancer (approximately 2-3\%).

BRCA-equivalent breast surveillance is recommended for the carriers of pathogenic variants in PALB2. Depending on the specific variant identified and the patient's family history, prophylactic risk-reducing breast surgery may be considered, although specific data regarding a survival advantage in carriers of PALB2 variants is lacking $[50,106]$. At present, there is insufficient evidence to recommend risk-reducing ovarian surgery in the carriers of PALB2 variants, but, in the absence of a proven benefit of ovarian cancer screening, it could be considered in the post-menopausal setting, after non-directive counselling.

PALB2 has a critical role in homologous recombination repair, such that tumours which are associated with pathogenic variants in PALB2 demonstrate homologous recombination repair deficiency [107], and there is increasing evidence to suggest that such tumours may demonstrate a favourable response to platinum-based chemotherapy and PARP inhibitors, such that the American College of Medical Genetics recommends the consideration of the same systemic options for the carriers of PALB2 variants as for carriers of pathogenic variants in $B R C A 1 / B R C A 2$ [106].

\subsection{RAD51C and RAD51D}

Two other proteins that function in the homology-directed repair of double stranded DNA breaks are RAD51C and RAD51D, which are encoded for by the RAD51C and $R A D 51 D$ genes, respectively. The association between germline pathogenic variants in these genes and ovarian cancer has been recognised for many years, but the association with breast cancer risk was only more recently established [108,109]. Previous studies have shown a particularly strong association between pathogenic $R A D 51 C$ and $R A D 51 D$ variants and oestrogen receptor negative or triple-negative breast cancer [110,111]. The breast cancer risk associated with such variants appears to be moderate, and is significantly modified by age and family history, with relative risks higher in those aged 20-49, and in those with a family history of early-onset breast cancer [109].

\subsection{Fanconi Anaemia}

Fanconi anaemia (FA) is a rare, genetically heterogeneous disorder that is associated with congenital anomalies, skeletal, ophthalmic, and genitourinary malformations, cutaneous manifestations, and a predisposition to malignancies-most typically haematological malignancies and squamous cell cancers. Fanconi anaemia can be inherited in an autosomal recessive manner, most commonly due to biallelic, pathogenic variants in FANCA, and less 
frequently due to biallelic variants in any of at least twenty genes, which include $B R C A 2$, $P A L B 2, R A D 51 C$, and very rarely, BRCA1 [112]. Biallelic variants in BRCA1 were traditionally believed to either be embryonically lethal, or a rare cause of Fanconi anaemia; however, increasing numbers of cases are being reported with phenotypes which overlap between Fanconi anaemia and other chromosome instability syndromes, particularly Nijmegen Breakage Syndrome; this has an associated risk of early-onset breast and/or ovarian cancer predisposition [113-116]. The individuals affected by early-onset breast cancer in these reports had other suggestive syndromic features.

In a proband with suspicious clinical findings, a diagnosis of FA can be determined by chromosome breakage analysis of lymphocytes treated with diepoxybutane (DEB) and mitomycin C [117], with subsequent testing of germline DNA using a panel of known FA-associated genes to establish the underlying genotype [118].

A diagnosis of Fanconi anaemia in a family has wide-ranging implications-each sibling of an individual with autosomal recessive FA has a $25 \%$ risk of being affected with the same disorder, and a $50 \%$ risk of being a heterozygous carrier of one variant allele, while the parents of such individuals are likely to be heterozygous carriers. Heterozygous carriers of variants in a gene associated with autosomal recessive forms of FA are not at risk of FA, but may be at increased risk of breast, ovarian, and/or other cancers, if the monoallelic variants in question are in BRCA1, BRCA2, PALB2, BRIP1 or RAD51C. However, some FA-associated variants may be hypo-morphic, and cause FA only when found in trans with a different pathogenic variant. Heterozygous carriers of hypo-morphic alleles in cancer predisposition genes may be at an only moderately, or slightly, increased cancer risk [119].

\subsection{ATM}

ATM plays a major role in maintaining genomic stability where it functions in the DNA damage response, but also in controlling the cell cycle and mitotic recombination [120,121]. Biallelic pathogenic variants in ATM give rise to ataxia-telangiectasia syndrome. The features of ataxia-telangiectasia syndrome are usually evident from childhood, and include progressive ataxia, cutaneous and ophthalmic telangiectasia, as well as an increased risk of cancer. The most common malignancies in individuals with A-T are haematological, including leukaemias and lymphomas, however, solid organ cancers, including breast cancers, are being increasingly noted as the survival of affected individuals improves, as well as in the carriers of certain ATM haplotypes or hypo-morphic alleles. The treatment of solid organ cancers in individuals with A-T should avoid radiotherapy, as A-T confers exquisite hypersensitivity to ionising radiation, with increased susceptibility to second primary cancers and radiotherapy-related complications. Certain A-T families have also demonstrated adverse chemotherapy-related effects [122-124].

A-T is very rare, with a prevalence of 1 in 40,000 to 1 in 100,000, and the Hardy Weinberg principle dictates that this translates to a carrier frequency of at least 1 in 100 . Monoallelic variants are associated with a moderately increased lifetime risk of breast cancer, over 20\%, which is greatest for patients under 50 years of age $[29,125,126]$. Certain variants confer higher risk. In general, truncating variants appear to confer a higher risk than missense variants [32], but a recurrent missense variant c.7271T > G (p.Val2424Gly) is associated with a particularly high breast cancer risk, in the order of $60 \%$ [127]. In the UK, BRCA-equivalent screening for carriers of this particular high-risk missense variant is provided via the national very high-risk breast screening programme. Female heterozygous carriers of other pathogenic ATM variant are recommended to have increased breast surveillance starting from the age of 40 . The frequency and duration of increased screening may be guided by the genotype and family history. MRI is favoured over mammography in homozygous/compound heterozygous carriers. Depending on the variant and the family history, prophylactic risk reducing surgery may be considered [50]. 


\subsection{CHEK2}

The checkpoint kinase protein CHEK2 is a tumour suppressor involved in DNA damage response pathways. While the majority of pathogenic germline variants in CHEK2 are associated with a moderately increased risk of breast cancer, certain variants may confer a higher risk of disease $[128,129]$, and others with a more modest risk. The recurrent variant, c.1100delC, is prevalent in up to $2 \%$ of individuals of North European ancestry; while other truncating variants (c.444 + 1G > A, deletion of exons 9-10 (del5395)) are particularly common in individuals of Czech, Slovak or Polish ancestry, and are associated with at least a moderate disease risk. Carriers of high risk CHEK2 variants are offered enhanced breast cancer surveillance $[31,130,131]$, with the frequency and duration of enhanced screening guided by their family history. At present, in the UK, formal guidelines are lacking. It is accepted practice that the carriers of truncating variants in CHEK2 are offered at least "moderate" risk screening, with annual mammograms starting from the age of 40 and continuing until the age of 50, with screening thereafter as part of the national breast cancer screening programme. The carriers of truncating variants in CHEK2 that have a strong family history of breast cancer are offered high intensity surveillance, with annual mammograms between the ages of 40-60 years. In families where there is a strong family history of breast cancer, non-carriers of the familial CHEK2 variant may still be offered moderate risk surveillance, because of the potential of other co-existing familial variants that have not been identified. Consideration of "very high risk" breast screening with annual MRI, as well as mammograms, should be considered for biallelic carriers of truncating CHEK2 variants, but this is determined on a case-by-case basis. Missense variants in CHEK2 are associated with a lower disease risk [32], and a recurrent missense variant (c.470T > C, p.I157T) is considered a low-penetrance allele [132]. Screening of the carriers of such variants is contingent on the family history rather than genotype alone.

Pathogenic variants in CHEK2 are associated with bilateral disease and an oestrogenpositive phenotype, and in the affected AYA are associated with reduced disease-free rates and overall survival $[133,134]$. The risk conferred by the c.1100delC variant is greatly modified by family history and is also modified by co-inherited genetic modifiers. The use of a polygenic risk score, which is derived from the variation at 77 loci, can categorise the heterozygous carriers of CHEK2 c.1100delC into risk categories, with the OR of those in the highest quintile of PRS of 2.03 [0.86-4.78], compared to 0.52 [0.16-1.74] for those in the lowest quintile [135]. Because of the relatively common carrier frequency, homozygous carriers of the CHEK2 c.1100delC variant are not all that rare. Unlike other cancer predisposition genes, CHEK2 is not associated with a distinct recessive phenotype, but biallelic carriers have a higher cancer risk, and a tendency to develop cancer at younger ages [136,137].

\subsection{BARD1}

BRCA1 exists mostly as a stable heterodimer with BARD1 (BRCA1 associated RING domain 1). In this heterodimer form, the E3 ubiquitin ligase activity of BRCA1 is significantly increased [138]. This ligase activity is paramount in maintaining genomic integrity via the tumour suppressive function of BRCA1 [139]. The mechanisms by which this happens are not yet fully elucidated $[27,140]$. This ligase activity is disrupted when tumorigenic variants in BRCA1 hinder the interaction between BARD1 and BRCA1, suggesting that similar complex-destabilising variants in BARD1 may promote tumorigenesis. A recent multicenter association study of more than 113,000 women found that protein-truncating variants in BARD1 were significantly associated with breast cancer, and most strongly with ER-negative and triple-negative disease [32]. This and other data suggest that BARD1 variants confer a low-moderate risk of breast cancer susceptibility [32]. Association with other cancers, and optimal risk management, have yet to be determined.

\section{Syndromic Causes of Early-Onset Breast Cancer}

Highly penetrant pathogenic variants in PTEN, TP53, STK11 and CDH1 confer a lifetime risk of breast cancer greater than $40 \%$ [41,141,142]. Pathogenic variants in such 
genes are very rare in the general population, conferring a predisposition to specific cancer syndromes as detailed below.

\subsection{PTEN}

PTEN is well known as one of the most frequently somatically mutated tumour suppressors in human cancer. Somatic driver events in PTEN have been identified in an array of malignancies, including brain, prostate, and breast cancers [143]. Heterozygous germline variants give rise to a number of rare, autosomal dominant syndromes that are collectively described under the umbrella term of PTEN hamartoma tumour syndrome (PHTS), which encompasses Cowden syndrome [144], Bannayan-Riley-Ruvalcaba syndrome [145], and Proteus and Proteus-like syndrome [146]. PTEN is a multi-functional protein which exerts its tumour suppressor capabilities in numerous processes, including the maintenance of genomic stability, cell survival, proliferation, migration, invasion, and metabolism [147]. Germline pathogenic variants in PTEN predispose an individual to several types of benign and malignant neoplasia, conferring a high risk of benign breast disease and breast cancer [148]. The estimated lifetime breast cancer risk in an individual with PHTS is between $67-85 \%$ [141], similar to that conferred by germline variants in BRCA1/BRCA2. The tumour phenotype of PHTS also includes benign and malignant neoplasia of the thyroid, kidney, endometrium, skin and gastrointestinal tract [148]. The carriers of germline PTEN variants often present in childhood or adolescence with non-neoplastic features, including macrocephaly, developmental delay, or arteriovenous malformations [149].

In addition to screening for breast and other related malignancies, PTEN variant carriers may be offered surgical prophylaxis $[50,150]$.

\subsection{STK11}

Heterozygous, pathogenic germline variants in the tumour suppressor gene STK11 are associated with the autosomal dominant disorder Peutz-Jeghers syndrome (PJS). Affected patients develop benign intestinal hamartomas and are also at a highly increased risk of developing other malignancies [142,151], including of the pancreas [152], breast [153], and reproductive organs [154]. For female patients diagnosed with PJS, the risk for developing breast cancer rises to $8,13,31$, and $45 \%$ at ages $40,50,60$, and 70 years, respectively [142]. Current recommendations advise that annual breast screening with MRI begin as a young adult, around 25 years. Where there is a strong family history of breast cancer, a discussion of prophylactic surgery may be considered, although there is still insufficient evidence to support this action [153].

\section{3. $\mathrm{CDH1}$}

Epithelial cadherin (E-cadherin) or cadherin-1 (CDH1) is a member of the cadherin superfamily. CDH1 is critical for cell adhesion, with roles in the regulation of cell polarity, differentiation and migration. E-cadherin expression is essential in normal embryonic development. Loss of E-cadherin is associated with the epithelial-mesenchymal transition (EMT), during which, epithelial cells demonstrate loss of apical-basal polarity and cellular adhesion, thereby acquiring the ability to migrate that leads, eventually, to metastatic dissemination. Loss of E-cadherin expression has been reported in gastric, colorectal, breast and ovarian cancers, with demonstrable changes in epithelial cell adhesion and motility. Loss of CDH1 activity results in increased cell motility leading to the increased metastatic ability of a tumour $[155,156]$. The associated cancer phenotype in heterozygous carriers of germline pathogenic variants in $C D H 1$ reflects a loss of function of E-cadherin, with increased risks of diffuse subtypes of gastric cancer, and/or lobular subtypes of breast cancer. The cumulative risk of lobular breast cancer in the female carriers of pathogenic $C D H 1$ variants by age 80 years is $39-55 \%$, with the average age of diagnosis being 53 years, while the cumulative risk of diffuse gastric cancer in male and female carriers of such variants is approximately $33-42 \%$ [157], with a median age of onset of 38 and the youngest reported case aged only 14 at diagnosis. 
In the carriers of a pathogenic $C D H 1$ variant with a personal or family history (first/second-degree relative) of diffuse gastric cancer, the associated cancer predisposition syndrome is termed hereditary diffuse gastric cancer. At present, the only proven method to minimise the risk of diffuse gastric cancer in the carriers of such variants is prophylactic gastrectomy, and in classic HDGC families this is recommended between the ages of 20-30. However, pathogenic $C D H 1$ variants are increasingly being identified among patients with early-onset lobular breast cancer, in the absence of a personal or family history of diffuse gastric cancer [158-160], leading to some authors to propose revising the name of the associated syndrome to "hereditary diffuse gastric and lobular breast cancer". Other authors propose that $\mathrm{CDH1}$-associated hereditary lobular breast cancer may represent a distinct syndrome. However, in some patients, lobular breast cancer may predate a diagnosis of diffuse gastric cancer, and families with HLBC will be recategorized as having HDGC if a diagnosis of diffuse gastric cancer is made in the proband or a family member. The population frequency of hereditary diffuse gastric cancer is estimated to be approximately 5-10 per 100,000 [157]. However, among women diagnosed with bilateral lobular breast cancer prior to age 70, the yield of the detection of germline pathogenic $C D H 1$ variants is $7 \%$ [161]. Lobular phenotypes of breast cancer in the carriers of pathogenic germline CDH1 variants can be confirmed by demonstration of p120-catenin staining in the cytoplasm; with negative staining for $\beta$-catenin; but there are no histopathological/immunohistochemical tests that can differentiate between lobular cancer which is associated with germline CDH1 variants and that associated with somatic variants in this gene [157].

Prophylactic gastrectomy in carriers of $\mathrm{CDH1}$ pathogenic variants without a personal/family history of gastric cancer may not be appropriate, given the significant morbidity associated with this intervention. The optimum approach to manage a hypothetical risk of gastric cancer in such families has yet to be determined [162].

Breast screening with MRI from age 25-30 is recommended for the female carriers of pathogenic or likely pathogenic $C D H 1$ variants $[50,163]$. MRI is preferable to mammograms because of the lobular phenotype. Risk-reducing surgery may be considered in cases with a strong family history of breast cancer [164].

Appendiceal signet ring cancers, as well as colorectal cancers, have also been reported in the carriers of $C D H 1$ variants, who have non-malignant features including cleft lip and palate. Germline variants in $C D H 1$ have also been reported as a cause of non-syndromic cleft lip and palate, and of familial Blephorocheilodontic (BCD) Syndrome, with or without an associated cancer risk $[165,166]$.

Therapeutic options in affected individuals, as well as the approach to surveillance in unaffected carriers, are also determined by their underlying genotype [40]. The knowledge that the carriers of such variants are at increased risk of radiation-induced second primary tumours means that radiotherapy is avoided where there is an alternative option that is at least non-inferior. In women affected by breast cancer, this means that mastectomy is favoured over breast-conserving surgery and radiotherapy. Similarly, surveillance protocols usually favour MRI compared to mammography — although the risk of mammographyinduced cancer does not appear to be drastically increased in such individuals and may be considered as an option for those patients for whom MRI is not acceptable.

\subsection{NF1}

NF1 is a large protein with several domains. Germline pathogenic variants in NF1 are associated with the autosomal dominant disorder, neurofibromatosis type 1 (NF1), which occurs as commonly as 1 in 2700 [167]. The features of NF1, which evolve over time, reflect an overgrowth of cells that are derived from differentiated glial cells, including melanocytes, Schwann cells, osteoblasts and chondrocytes. The most characteristic features of NF1 are the cutaneous manifestations, which include café au lait spots, axillary and inguinal freckling, and a tendency to develop simple and/or plexiform neurofibromas which give the condition its name. Affected individuals have an increased risk of developing an array of malignant tumours, including central nervous system glioma, gastro-intestinal stromal 
tumours, phaeochromocytomas, and pre-menopausal breast cancer [168]. The lifetime risk of breast cancer associated with pathogenic variants in NF1 is approximately $20 \%$, with a significant risk of developing breast cancer under the age of $50[30,169]$, such that it has been suggested that patients with NF1 should be referred for enhanced breast cancer screening [170]. However, a recent study of more than 113,000 women was unable to definitively show an association between NF1 and breast cancer risk [32]. Risk estimation and management should be individualised depending on the genotype and family history.

A clinical diagnosis of NF1 should be considered based on the clinical criteria as outlined in Table 1 [171]. Cutaneous findings may be subtle, and examination with a Woods lamp is indicated to identify features that might not be obvious otherwise. Germline mosaicism leading to segmental phenotypes is not uncommon. Confirmation by analysis of the NF1 gene facilitates cascade genetic testing, preimplantation testing and/or prenatal testing; and mRNA analysis is preferred to DNA sequencing to increase the diagnostic yield.

Table 1. Clinical diagnostic criteria for NF1.

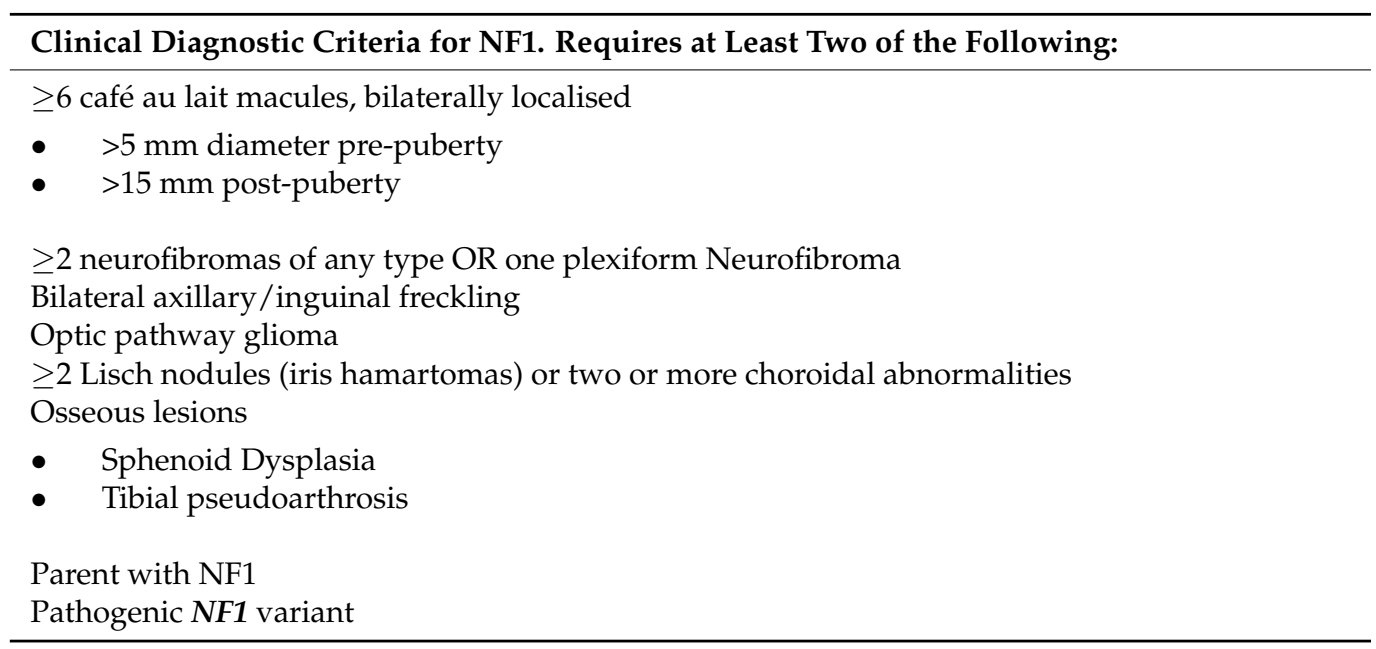

\section{Putative High/Moderate Risk Genes}

Variants in a number of other genes (including $M R E 11, N B N$ ) have been postulated to be associated with an increased breast cancer risk, but their association has not, as of yet, been proven. Breast cancer has been reported as part of the phenotypic spectrum of the rare, recessive, NTHL1 tumour predisposition syndrome, with a median age of onset of 49 years (38-63) [172]. More common features of this condition include colorectal polyps (adenomatous, hyperplastic or sessile serrated), as well as colorectal and extracolonic cancers. Exploring the association between these candidate genes and breast cancer risk is beyond the scope of this review

\section{Common, Low-Risk Variants}

Hundreds of single nucleotide polymorphisms (SNPs) at loci scattered throughout the genome have been identified that are associated with a very slightly increased risk of breast cancer $[173,174]$. Most low-risk SNPs are located in intragenic regions.

While the individual risk conferred by these SNPs is small, they are at least additive; homozygous carriers are at an increased risk of disease over heterozygotes [174]. Lowpenetrance SNPs are not routinely evaluated during the clinical assessment of breast cancer risk, though it is estimated that these SNPs may account for up to $18 \%$ of the inherited risk of breast cancer [173]. It is possible that the combined effect of co-inherited low-penetrance SNPs may be associated with a significantly increased risk of disease. Research is ongoing to determine if polygenic risk scores (PRS) can be utilised to stratify breast cancer risk in the general population and in high-risk variant carriers [175-179]. Most PRS have been derived from data related to individuals of European Caucasian ancestry, and therefore may not be applicable for other patient groups. 


\section{Overview of Environmental and Lifestyle Risk Factors for Breast Cancer}

A number of environmental and lifestyle factors have been identified as risk factors for breast cancer. For breast cancer, these environmental and lifestyle factors include an exposure to ionizing radiation, exogenous hormones and reproductive choices, diet and alcohol consumption, obesity, and physical inactivity [180-182].

\subsection{Hormonal Contraception and Reproductive Preferences}

Between 2017-2019, 14\% of women aged 15-49 years in the United States were using oral contraceptive pills (OCP) [183]. OCP use decreases with increasing age: approximately 1 in 5 women aged 15-19 and 20-29 use a form of OCP, versus 1 in 10 women aged 30-39 and 1 in 15 women aged 40-49 [183]. The risk of developing breast cancer as the result of OCP use has been a controversial debate for many years. Previous studies [184] showing an association to breast cancer have been criticised as outdated, given that today's contraceptives offer lower levels of oestrogen, newer progestins, and newer delivery routes [185]. In 2017, using nationwide registries from 1995-2012, a large prospective cohort study of 1.8 million Danish women investigated the association between contemporary hormonal contraceptive (CHC) use and breast cancer [186]. When compared to women who had never used hormonal contraception, a relative risk of breast cancer of 1.2 was identified for women who were current or recent CHC users [186]. This risk increased from 1.09 for users of less than 1 year to 1.38 for users of more than 10 years [186]. For women taking $\mathrm{CHC}$ in excess of 5 years, the risk persisted following cessation of use. The relative risk for women using a progestin-only intrauterine system was also elevated at 1.21 versus never-users [186]. The overall absolute risk of breast cancer for all methods was modest and translated to approximately 1 extra breast cancer for every 7690 women using hormonal contraception for 1 year [186]. The absolute risk of invasive breast cancer was significantly more modest for those aged under 35 years, at approximately 1 extra case for every 50,000 women using CHC [186]. However, the context in which these findings are interpreted is important. $\mathrm{CHC}$ use is associated with a decreased risk of developing ovarian, endometrial, and colon cancers, and overall cancer risk may be lower in CHC users than in never-users [187,188].

In addition, the Danish study did not account for the confounding influence of factors such as alcohol consumption, physical inactivity, and breastfeeding. When considering the contraceptive and non-contraceptive benefits of $\mathrm{CHC}$ use, the overall benefit likely outweighs the small increased risk of breast cancer for most women. Patient factors such as a family history of disease, BMI, age, and intended duration of use should be considered when choosing a CHC method $[189,190]$.

The age of someone's first full-term pregnancy and their number of pregnancies can modulate breast cancer risk. The short-term risk of developing breast cancer increases for approximately 20 years, peaking after 5 years, following a pregnancy, and most significantly for those with a prior family history of disease [191,192]. This elevated hazard ratio is not observed for women whose first pregnancy occurred under the age of 25 years [191,192]. However, the overall lifetime risk of developing breast cancer is reduced for women whose first pregnancy was before the age of 30 [192]. A late first pregnancy ( $>35$ years of age) is associated with an increased lifetime risk of breast cancer [192]. This further demonstrates that the risk factors of breast cancer differ between the AYAs and older adult population.

\subsection{Obesity}

Body mass index (BMI) is used as a tool for indicating nutritional status and is calculated by dividing a person's weight in kilograms by the square of their height in metres $\left(\mathrm{kg} / \mathrm{m}^{2}\right)$. The World Health Organisation (WHO) defines pre-obesity (overweight) and obesity as a BMI $\geq 25 \mathrm{Kg} / \mathrm{m}^{2}$ and $\geq 30 \mathrm{Kg} / \mathrm{m}^{2}$, respectively [108]. The rates of obesity are rising similarly in Ireland, the UK, and the USA, where almost $70 \%$ of adults are overweight, and one in three is classed as obese [193-195]. Several studies have consistently demonstrated the association between increased BMI and an array of health conditions, 
including diabetes, hypertension, cardiovascular diseases [196], and cancers including postmenopausal breast cancer [197-199]. While the literature is somewhat conflicting, several studies indicate an inverse association between breast cancer risk and a greater BMI during adolescence and early adult years ([200-202] and references therein). This risk then inverts at a certain point in adulthood. A meta-analysis of over 1000 studies demonstrated a relative risk of 1.1 per $5 \mathrm{BMI}$ units of postmenopausal breast cancer, particularly oestrogen receptor-positive disease, in women with a greater BMI [203]. Obesity at the time of diagnosis is associated with a poorer prognosis and 30\% higher overall recurrence and mortality risk [204-206].

\subsection{Physical Activity}

Several studies have observed a favourable association between moderate physical activity and reduced breast cancer risk [207-215]. This reduction in cancer risk may be as significant as $20 \%$, including for those with a family history of disease [214]. The benefit of low and high physical activity has been observed for both pre- and postmenopausal women [212], although it has been suggested that the most benefit may be derived from high levels of physical activity throughout adolescence and adulthood [210]. While breast cancer risk reduces with an increasing intensity of exercise [216], an optimal exercise regime to reduce cancer risk is yet to be determined. The World Cancer Research Fund recommends at least 30 min of moderate physical activity daily and an overall reduction in sedentary behaviours [217]. Considering the previously mentioned paradoxical effect of high BMI on pre- and postmenopausal breast cancer risk, the risk reduction conferred by physical activity is likely to be mediated through factors other than weight control. It has been suggested that physical activity may mediate breast cancer risk by decreasing insulin levels [209] and influencing insulin-like growth factors and binding proteins [218,219].

\subsection{Diet}

Studies into how diet can influence breast cancer risk are difficult to conduct given confounding factors such as alcohol consumption and the accuracy of nutrient measurement. Many of these studies to date have yielded conflicting and inconclusive results with regards to breast cancer risk. Some studies have indicated that a Mediterranean diet that is rich in fruits and vegetables, fish and olive oil, decreases the incidence of breast cancer [220], particularly oestrogen-receptor-negative disease [221-223]. A 2010 meta-analysis reported a diet that is rich in fruits and vegetables is associated with a reduced risk of breast cancer [224]. This relationship was not observed in a prospective study of over 993,000 women [225]. A study of nearly 91,000 women identified a $15 \%$ reduced risk of premenopausal breast cancer that was associated with a higher fruit and vegetable intake (2.9 servings/day) during adolescence and early adulthood [226].

Studies investigating the impact of dietary fat intake and breast cancer risk have also yielded conflicting results. A large US cohort study of 188,736 postmenopausal women found that dietary fat intake contributed directly to the risk of invasive postmenopausal breast cancer [227]. Women consuming the highest fat ( $40.1 \%$ energy from fat) had breast cancer rates $11-22 \%$ higher than those of women consuming the lowest amounts of fat ( $20.3 \%$ energy from fat). A subsequent meta-analysis of several cohort studies failed to replicate a significant association between dietary fat intake and breast cancer risk [228]. While inconclusively a risk factor for disease onset, several studies have found that a low-fat dietary intake is associated with a lower incidence of deaths following breast cancer diagnosis $[225,229,230]$.

It had previously been postulated that as soy products contain phytoestrogens (isoflavo nes), excessive consumption could lead to an increase in oestrogen levels, and thus increase the risk of breast cancer [231]. However, nations with the highest soy consumption observe the lowest incidence and death rates of breast cancer. Several studies and meta-analyses have indicated that a moderate consumption of soy products confer a protective effect against pre- and postmenopausal breast cancer [232-235]. 


\subsection{Alcohol Consumption}

Alcohol consumption has been associated with several cancer types [236]. Alcohol consumption of any kind has been consistently associated with an increased risk of breast cancer [236-242]. As little as one drink per day, or 3-6 per week, contributes to this risk $[237,238,240,243]$. When compared to low-level drinkers ( $<60$ drinks/year), those who had ever participated in binge drinking or who had blacked out showed increased risk of disease [243,244]. For each $10 \mathrm{~g}$ of alcohol consumed per day there was a $12 \%$ increase in breast cancer risk identified [238]. There were no differences observed for different alcohol types. Breast cancer risk increases linearly with cumulative lifetime alcohol consumption [243]. The same pattern of association and risk is observed for alcohol consumption levels between the ages of 18 and 40 years and for those over 40 years of age [243]. The proportion of breast cancers that can be attributed to alcohol varies from $2 \%$ in the USA [245] to 5\% in Western Europe [246]. In countries where the overall alcohol consumption is higher or binge drinking is common, such as in Ireland and Italy, the proportion of breast cancers that can be attributed to alcohol is as high as $12 \%[246,247]$.

\subsection{Previous Irradiation/Prior Childhood Cancers}

It is well established that individuals who are exposed to ionising radiation during childhood, adolescence, or young adulthood are at an increased risk of developing a subsequent breast cancer. This radiation exposure may occur in diagnostic or therapeutic settings, such as in the case with Hodgkin lymphoma [248,249], or environmental, through the exposure to radiation via atomic bomb or nuclear disaster [250]. The risk of radiationinduced breast cancer is greatest for children who are exposed between the ages of 10 and 14 years, while exposure after 40 years of age increases the risk of breast cancer only marginally [251]. The risk of disease is also dependent on the dose of radiation given. This highlights the importance of the dosage during mammographic screening for breast cancer, given the low levels of radiation a patient is exposed to at regular intervals over a number of decades [252,253]. Several computational simulations of radiation-induced breast cancer in high-risk individuals suggest an optimal screening regime of MRI starting at age 25, with subsequent combined use of MRI with mammography starting at age 30 [254-256].

\subsection{Breast Cancer Risks in Sexual and Gender Minorities (SGMs)}

The risk of breast cancer in non-binary, transgender or intersex individuals is different to that of cisgender individuals, being significantly modified by factors such as hormone therapy, gender-confirming surgery, and surveillance, as well as those factors associated with breast cancer risk in cis-gender individuals. Breast cancer risk among transwomen has been found to be lower than that of ciswomen, but significantly increased when compared to cisgender males-in the order of 46-fold higher [257].

Identification of a high risk of breast cancer among such individuals is important, to direct screening and other risk-reducing strategies. Careful consideration should be given to such interventions, given the significant psychological distress that may be associated with them. An inclusive and sensitive approach to the risk estimation and management of individuals from sexual and gender minorities is critical [258].

Many transmen may choose to undergo bilateral mastectomy ("top surgery") as part of their transition. Cases of breast cancer occurring in residual breast tissue in transmen who undergo such surgery have been reported [259-263]. The identification of a high risk of breast cancer in the individuals undergoing such surgery is important, so that an oncologic/preventative approach can be undertaken rather than the standard approach for masculinizing chest surgery. Depending on the health system, oncologic surgeries are likely to be prioritised over cosmetic surgeries, and therefore identification of a high breast cancer risk may determine waiting times for such surgery, and impact whether or not an insurance provider will cover the operation. 


\section{Holistic Risk Assessment}

To provide an accurate estimate of risk in AYAs (and indeed in older patients), a holistic approach is required, bearing in mind lifestyle and reproductive factors as well as breast density, family history and heritable predisposition [264]. The risk factors outlined in this paper are summarised in Table 2.

Table 2. Summary of risk factors for breast cancer.

\begin{tabular}{|c|c|c|c|}
\hline Risk Factor & Risk & Action & $\begin{array}{l}\text { Population Frequency of } \\
\text { Pathogenic Variants }\end{array}$ \\
\hline \multicolumn{4}{|c|}{ Inherited Predisposition } \\
\hline \multicolumn{4}{|l|}{ Monogenic Variants } \\
\hline TP53 & $80-90 \%$ & Yearly breast MRI starting at 20 years & $1 / 3555$ to $1 / 5476$ \\
\hline BRCA1 & $65-79 \%$ & $\begin{array}{l}\text { MRI and/or mammogram starting at } \\
25-30 \text { years }\end{array}$ & $1 / 381$ \\
\hline$B R C A 2$ & $61-77 \%$ & $\begin{array}{l}\text { MRI and/or mammogram starting at } \\
25-30 \text { years }\end{array}$ & $1 / 277$ \\
\hline PALB2 & $44 \%$ to $63 \%$ & $\begin{array}{l}\text { MRI and/or mammogram starting at } \\
\text { 25-30 years }\end{array}$ & $1 / 770$ \\
\hline RAD51C & $15-29 \%$ & $\begin{array}{l}\text { Annual mammogram from } 40-50 / 60 \\
\text { depending on family history }\end{array}$ & $1 / 880$ \\
\hline$R A D 51 D$ & $14-28 \%$ & $\begin{array}{l}\text { Annual mammogram from } 40-50 / 60 \\
\text { depending on family history }\end{array}$ & $1 / 1680$ \\
\hline ATM & OR 2.10 (1.71-2.57) & $\begin{array}{l}\text { Increased screening with MRI } \\
\text { starting at } 40 \text { years }\end{array}$ & $1 / 100$ \\
\hline CHEK2 & OR $2.54(2.21-2.91)$ & $\begin{array}{l}\text { Annual mammography from } 40-50 \\
\text { years, general screening thereafter }\end{array}$ & $1 / 100$ \\
\hline BARD1 & OR 2.09 (1.35-3.23) & Risk management not yet determined & $1 / 1100$ \\
\hline \multicolumn{4}{|l|}{ Syndromic causes } \\
\hline PTEN & $\sim 85 \%$ & $\begin{array}{l}\text { MRI and/or mammogram starting at } \\
25-30 \text { years }\end{array}$ & $1 / 200,000$ \\
\hline STK11 & $45-54 \%$ & MRI starting at 25 years & $1 / 25,000-1 / 280,000$ \\
\hline CDH1 & $23-68 \%$ & MRI starting at $25-30$ years & $<0.1 / 100,000$ \\
\hline NF1 & SMR 5.20 (2.38-9.88) & Risk management not yet determined & $1 / 1900-1 / 3000$ \\
\hline $\begin{array}{l}\text { Common, low-risk } \\
\text { variants }\end{array}$ & Low & No action & \\
\hline \multicolumn{4}{|c|}{ Lifestyle factors } \\
\hline \multicolumn{4}{|c|}{ Hormonal contraception and reproductive preferences } \\
\hline CHC use & Modest & $\begin{array}{c}\text { CHC use should be directed by } \\
\text { family history. In general, the benefits } \\
\text { largely outweigh increased risk of } \\
\text { breast cancer }\end{array}$ & \\
\hline Age at first pregnancy & $\begin{array}{l}\text { - } \quad \text { Decreased risk if first } \\
\text { pregnancy }<30 \text { years } \\
\text { - } \quad \text { Increased risk if first } \\
\text { pregnancy }>35 \text { years }\end{array}$ & & \\
\hline
\end{tabular}


Table 2. Cont.

\begin{tabular}{|c|c|c|c|}
\hline Risk Factor & Risk & Action & $\begin{array}{l}\text { Population Frequency of } \\
\text { Pathogenic Variants }\end{array}$ \\
\hline Obesity & $\begin{array}{l}\text { Decreased risk with } \\
\text { greater BMI in } \\
\text { childhood and } \\
\text { adolescents } \\
\text { - Increased risk with } \\
\text { greater BMI in } \\
\text { adulthood }\end{array}$ & & \\
\hline Physical Activity & $\begin{array}{l}\text { Reduced risk associated } \\
\text { with moderate physical } \\
\text { activity. Further reduction } \\
\text { with increasing activity } \\
\text { level }\end{array}$ & $\begin{array}{l}\text { Optimal exercise regime yet to be } \\
\text { determined. WHO recommends } \geq 30 \\
\text { min of moderate physical activity } \\
\text { daily, and an overall reduction in } \\
\text { sedentary behaviours }\end{array}$ & \\
\hline Diet & Inconclusive data & & \\
\hline $\begin{array}{l}\text { Alcohol } \\
\text { Consumption }\end{array}$ & $\begin{array}{l}\text { Increased risk with any } \\
\text { consumption, increasing } \\
\text { linearly with cumulative } \\
\text { lifetime alcohol } \\
\text { consumption }\end{array}$ & & \\
\hline $\begin{array}{l}\text { Radiation } \\
\text { Exposure/Childhood } \\
\text { Cancer }\end{array}$ & $\begin{array}{l}\text { Greatest risk for children } \\
\text { exposed between the ages } \\
\text { of } 10 \text { and } 14 \text { years }\end{array}$ & $\begin{array}{l}\text { Risk management not yet determined. } \\
\text { Computational algorithms suggest } \\
\text { MRI starting at age } 25 \text {, combined with } \\
\text { mammography starting at age } 30\end{array}$ & \\
\hline $\begin{array}{l}\text { Sexual and Gender } \\
\text { Minorities }\end{array}$ & $\begin{array}{l}\text { Risk for transgender } \\
\text { women lower than } \\
\text { cisgender women but } \\
\text { significantly higher than } \\
\text { cisgender men }\end{array}$ & $\begin{array}{l}\text { Identification of other high-risk } \\
\text { factors to direct screening and other } \\
\text { risk-reducing strategies }\end{array}$ & \\
\hline
\end{tabular}

CHC: contemporary hormonal contraceptive; BMI: body mass index; WHO: World Health Organisation.

Several models have been developed to assist clinicians in quantifying an individual's lifetime risk of breast cancer, and since the discovery of the genes that are associated with monogenic predisposition, many have been developed to also include an estimation of the risk of carrying a high-risk variant in a breast cancer susceptibility gene [265].

\subsection{Gail and Claus Models}

The Breast Cancer Risk Assessment Tool, traditionally known as the Gail model, was developed in 1989 [266], and the Claus model since the early 90s [267].

The Claus model, which is based on data from the Cancer and Steroid Hormone study, allows an estimation of cancer risk that is based on family history and hereditary factors only [267]. The Gail model includes data regarding ethnicity, age, age at menarche, age at first pregnancy, family history, and the presence of atypical ductal hyperplasia. Initially developed using data from the Breast Cancer Detection Demonstration Project [266], which primarily included white women, the model has been adapted to include data related to black, Hispanic, Asian, and Pacific Islander women, using data from the Contraceptive and Reproductive Experiences (CARE) study, the California Surveillance, Epidemiology, and End Results (SEER) Program, the San Francisco Bay Area Breast Cancer Study, the California Cancer Registry, and the Asian American Breast Cancer Study [268-270]. The model underperforms for certain ethnic groups and is not accurate for patients with a previous history of invasive or in situ ductal or lobular breast carcinoma, nor for those with a preceding history of breast wall irradiation. Furthermore, it is not accurate for use 
in the known carriers of pathogenic variants in $B R C A 1$ or $B R C A 2$, or other breast cancer susceptibility genes.

\subsection{BRCAPRO}

The BRCAPRO model is a Bayesian tool that incorporates information regarding population frequencies of pathogenic variants in $B R C A 1$ and $B R C A 2$, penetrance estimates, as well as personal and family history of cancer-including data related to unaffected as well as affected relatives - to generate estimates of breast cancer risk as well as the probability of identifying a high-risk germline variant [271].

\subsection{Tyrer-Cuzick Model}

The Tyrer-Cuzick model includes data from the International Breast Intervention Study. Compared to other models, this tool allows the incorporation of genotypes related to other cancer susceptibility genes which include $B R C A 1$ and $B R C A 2$, as well as family history, reproductive risk factors and ductal atypical hyperplasia [272].

\subsection{BOADICEA and CanRisk}

The Breast and Ovarian Analysis of Disease Incidence and Carrier Estimation Algorithm (BOADICEA) model incorporates information regarding BRCA1 and BRCA2 genotype, as well as polygenic risk and family history. BOADICEA has now been superseded by CanRisk [273]. CanRisk is a CE-marked tool which allows a clinician to enter data pertaining to lifestyle and reproductive risk factors, as well as family history and germline genetic risk factors-including high risk traits and polygenic risk scores. The tool allows an individualised estimation of lifetime breast cancer risk in the carriers and non-carriers of variants in BRCA1, BRCA2, PALB2, CHEK2, ATM, RAD51C, RAD51D, and $B R I P 1$, and considers these modifiers of disease which may inform risk management. The tool does not permit genotype-specific information, so the user should bear this in mind when considering variants associated with reduced penetrance. The adage of "garbage in, garbage out" is particularly relevant when using these tools-care should be taken to verify family history and genotype where possible.

For individuals that have not yet had germline genetic testing, this tool can also estimate the a priori probability of identifying a pathogenic germline variant in one of these genes. In the UK, this is used to direct testing, as current guidelines permit NHS-funded germline testing where this probability is at least $10 \%$-AYAs with breast cancer will meet this threshold with relatively little or no family history depending on the age at diagnosis.

The tool does not include information related to syndromic causes of breast cancer, precluding use of this tool to generate risk estimates in the known carriers of pathogenic variants in CDH1, PTEN, TP53, or STK11. In order to identify the carriers of such variants, the clinician should be alert to the phenotypes associated with rare syndromic causes of breast cancer.

Where PTEN hamartoma tumour syndrome is a consideration, the Cleveland Clinic PTEN calculator is a useful tool to estimate the likelihood of identifying a germline pathogenic variant in PTEN [274]. Clinical diagnostic criteria have been developed for this and other syndromic disorders, which may be useful in directing testing, or, importantly, in providing a clinical diagnosis to help guide management where germline genetic testing is uninformative $[153,157,275,276]$.

\subsection{Deep Learning and Emerging AI}

Current screening for breast cancer relies on the physical exam, mammography, and, in selected patients, MRI. Mammography largely relies on the 5th edition of the BI-RADS scoring system to score images 0 to 6 , with 0 being incomplete or inconclusive imaging and 6 being known, biopsy-proven malignancy.

Recently, advancements in artificial intelligence (AI) have led to the development of systems that are potentially capable of surpassing human experts in breast cancer prediction. 
Zhu et al. analysed mammograms that were obtained in 6369 women without breast cancer, 1609 of whom developed screening-detected breast cancer, and 351 of whom developed interval invasive disease. This case-case-control study found that AI or deep learning systems outperformed clinical risk factors, including breast density, in detecting the screening-detected cancer risk but underperformed for detecting interval cancer risk [277].

Another recent article in the journal of Nature compared an AI system to human experts in the United Kingdom and USA in predicting breast cancer. To assess the AI's performance in the clinical setting, the authors curated a large dataset from the UK and USA. They showed that the AI system resulted in an absolute reduction of $5.7 \%$ and $1.2 \%$ (USA and UK) in false positives and $9.4 \%$ and $2.7 \%$ in false negatives [2]. Furthermore, in an independent study of six radiologists, the AI system outperformed all human readers; the area under the receiver operating characteristic curve (AUC-ROC) for the AI system was greater than the AUC-ROC for the average radiologist by an absolute margin of $11.5 \%$ [278].

Ming et al. investigated the classification of lifetime breast cancer risk based on three different machine learning (ML) algorithms and the BOADICEA model in 112,587 individuals [279]. ML algorithms were found to have greater predictive accuracy than that of BOADICEA, reclassifying $35.3 \%$ of women in different risk categories [279]. The largest impact was observed in the screening for women younger than 50 years [279].

Further studies are required to explore the translational applications of these approaches.

\section{Testing: When, Who, How and Why}

In the UK and other countries with public health systems, germline genetic testing is often restricted to single genes or narrow gene panels and offered only to individuals who fulfill certain criteria. However, there is an increasing move towards broader gene panels, or whole exome/genome approaches. Broader testing optimises the cost- and time-efficiency and maximises the diagnostic yield. However, such testing also increases the potential for uncertainty and unexpected results. Some proponents of this approach argue that the identification of unexpected variants is an opportunistic advantage-facilitating risk-reducing strategies that may not otherwise have been offered based on the personal/family history. Broader approaches are particularly useful in individuals with atypical phenotypes, or where more than one heritable cancer predisposition syndrome is suspected. Finding more than one germline pathogenic variant, known as Multilocus Inherited Neoplasia Alleles Syndrome, is not all that rare; this is a particular risk in certain ethnic groups where the prevalence of founder mutations is high. "Double heterozygosity" or "transheterozygosity" of variants in both $B R C A 1$ and $B R C A 2$ is a rare event, and the associated phenotype is a mix of those found in BRCA1 and BRCA2 heterozygous carriers [275]. Double heterozygosity is a particular risk in individuals of Ashkenazi Jewish heritage, where carrier frequency of variants in $B R C A 1$ or $B R C A 2$ is relatively high.

Much of the additional diagnostic yield of broad cancer gene panels relates to the identification of variants associated with moderate, or uncertain, risks of breast cancer. This creates significant challenges in the clinical management of the carriers of such variants-as well as carrier and non-carrier relatives. In an AYA with a strong personal and family history of breast cancer, a variant associated with a moderate or low penetrance is likely to account only for a proportion of the disease risk. The residual risk may be attributable to environmental, lifestyle, or unidentified risk factors; however, a proportion may also be attributed to other co-inherited germline genetic variants that have not been detected. Risk management in such carriers should therefore consider family history and other modifying risk factors as well as the genotype; in non-carriers in families where a moderate risk allele has been identified, continued surveillance and/or other risk-reducing strategies may still be warranted. 


\section{Conclusions}

Breast cancer in AYAs is relatively rare, and a significant proportion of risk is attributable to high-risk germline genetic variants, such that germline genetic testing should always be considered in affected individuals. A "negative" germline genetic test does not exclude the possibility of heritable risk factors, and enhanced cancer screening in the proband and close relatives is warranted and should be guided by the family history. For accurate risk estimation, a holistic approach is needed, that considers not only high-risk genotypes, but other modifiers of risk-including reproductive and lifestyle risk factors, and co-existing genetic modifiers, including the polygenic risk score, where available. Careful phenotyping in an AYA with breast cancer is crucial to avoid missing syndromic causes of breast cancer. In individuals for whom the lifetime breast cancer risk is estimated to be high, consideration should be given to surveillance, as well as chemo- and/or surgical prophylaxis. Furthermore, the opportunity to instigate changes to modify risk, such as lowering alcohol intake, reducing body weight, or adjusting contraception, should be explored, as summarised in Table 2.

Author Contributions: U.M.M.-Conceptualisation, Literature review, Manuscript preparation and editing. J.W.T.-Literature review, manuscript preparation. T.P.M.-Conceptualisation, manuscript review and editing. All authors have read and agreed to the published version of the manuscript.

Funding: This research received no external funding.

Conflicts of Interest: The authors declare no conflict of interest.

\section{References}

1. Johnson, R.H.; Anders, C.K.; Litton, J.K.; Ruddy, K.J.; Bleyer, A. Breast cancer in adolescents and young adults. Pediatr. Blood Cancer 2018, 65, e27397. [CrossRef]

2. Cancer Research UK. Cancer Incidence by Age. 2020. Available online: https://www.cancerresearchuk.org/health-professional/ cancer-statistics/incidence/age\#heading-Two (accessed on 4 August 2021).

3. Fidler, M.M.; Gupta, S.; Soerjomataram, I.; Ferlay, J.; Steliarova-Foucher, E.; Bray, F. Cancer incidence and mortality among young adults aged 20-39 years worldwide in 2012: A population-based study. Lancet Oncol. 2017, 18, 1579-1589. [CrossRef]

4. Barr, R.D.; Ries, L.A.; Lewis, D.R.; Harlan, L.C.; Keegan, T.H.; Pollock, B.H.; Bleyer, W.A. Incidence and incidence trends of the most frequent cancers in adolescent and young adult Americans, including "nonmalignant/noninvasive" tumors. Cancer 2016, 122, 1000-1008. [CrossRef] [PubMed]

5. Bleyer, W.A. Cancer in older adolescents and young adults: Epidemiology, diagnosis, treatment, survival, and importance of clinical trials. Med. Pediatr. Oncol. 2002, 38, 1-10. [CrossRef] [PubMed]

6. Keegan, T.H.M.; DeRouen, M.C.; Press, D.J.; Kurian, A.W.; Clarke, C.A. Occurrence of breast cancer subtypes in adolescent and young adult women. Breast Cancer Res. 2012, 14, R55. [CrossRef] [PubMed]

7. Tichy, J.R.; Lim, E.; Anders, C.K. Breast Cancer in Adolescents and Young Adults: A Review with a Focus on Biology. J. Natl. Compr. Cancer Netw. 2013, 11, 1060-1069. [CrossRef]

8. Flaherty, D.C.; Bawa, R.; Burton, C.; Goldfarb, M. Breast Cancer in Male Adolescents and Young Adults. Ann. Surg. Oncol. 2017, 24, 84-90. [CrossRef]

9. Murphy, B.L.; Day, C.N.; Hoskin, T.L.; Habermann, E.B.; Boughey, J.C. Adolescents and Young Adults with Breast Cancer have More Aggressive Disease and Treatment Than Patients in Their Forties. Ann. Surg. Oncol. 2019, 26, 3920-3930. [CrossRef]

10. Sauder, C.A.; Li, Q.; Othieno, A.; Cruz, D.; Arora, M.; Bold, R.J.; Meyers, F.J.; Keegan, T.H. Characteristics and Outcomes for Secondary Breast Cancer in Childhood, Adolescent, and Young Adult Cancer Survivors Treated with Radiation. Cancer Epidemiol. Biomark. Prev. 2020, 29, 1767-1774. [CrossRef] [PubMed]

11. Youlden, D.R.; Baade, P.; Walker, R.; Pyke, C.M.; Roder, D.; Aitken, J.F. Breast Cancer Incidence and Survival among Young Females in Queensland, Australia. J. Adolesc. Young Adult Oncol. 2020, 9, 402-409. [CrossRef] [PubMed]

12. Cathcart-Rake, E.J.; Ruddy, K.J.; Bleyer, A.; Johnson, R.H. Breast Cancer in Adolescent and Young Adult Women under the Age of 40 Years. JCO Oncol. Pract. 2021, 17, 305-313. [CrossRef]

13. Merks, J.H.M.; Caron, H.N.; Hennekam, R.C. High incidence of malformation syndromes in a series of 1073 children with cancer. Am. J. Med. Genet. Part A 2005, 134A, 132-143. [CrossRef] [PubMed]

14. Zhang, J.; Walsh, M.F.; Wu, G.; Edmonson, M.N.; Gruber, T.A.; Easton, J.; Hedges, D.; Aman, P.; Zhou, X.; Yergeau, D.A.; et al. Germline Mutations in Predisposition Genes in Pediatric Cancer. N. Engl. J. Med. 2015, 373, 2336-2346. [CrossRef] [PubMed]

15. Gröbner, S.N.; Worst, B.C.; Weischenfeldt, J.; Buchhalter, I.; Kleinheinz, K.; Rudneva, V.A.; Johann, P.D.; Balasubramanian, G.P.; Segura-Wang, M.; Brabetz, S.; et al. The landscape of genomic alterations across childhood cancers. Nature 2018, 555, 321-327. [CrossRef] [PubMed] 
16. Parsons, D.W.; Roy, A.; Yang, Y.; Wang, T.; Scollon, S.; Bergstrom, K.; Kerstein, R.A.; Gutierrez, S.; Petersen, A.K.; Bavle, A.; et al. Diagnostic Yield of Clinical Tumor and Germline Whole-Exome Sequencing for Children With Solid Tumors. JAMA Oncol. 2016, 2, 616-624. [CrossRef] [PubMed]

17. Copson, E.R.; Maishman, T.C.; Tapper, W.J.; Cutress, R.I.; Greville-Heygate, S.; Altman, D.G.; Eccles, B.; Gerty, S.; Durcan, L.T.; Jones, L.; et al. Germline BRCA mutation and outcome in young-onset breast cancer (POSH): A prospective cohort study. Lancet Oncol. 2018, 19, 169-180. [CrossRef]

18. Peto, J.; Collins, N.; Barfoot, R.; Seal, S.; Warren, W.; Rahman, N.; Easton, D.F.; Evans, C.; Deacon, J.; Stratton, M.R. Prevalence of BRCA1 and BRCA2 Gene Mutations in Patients with Early-Onset Breast Cancer. J. Natl. Cancer Inst. 1999, 91, 943-949. [CrossRef] [PubMed]

19. Rummel, S.K.; Lovejoy, L.; Shriver, C.D.; Ellsworth, R.E. Contribution of germline mutations in cancer predisposition genes to tumor etiology in young women diagnosed with invasive breast cancer. Breast Cancer Res. Treat. 2017, 164, 593-601. [CrossRef]

20. Bayraktar, S.; Amendola, L.; Gutierrez-Barrera, A.M.; Hashmi, S.S.; Amos, C.; Gambello, M.; Ready, K.J.; Arun, B. Clinicopathologic characteristics of breast cancer in BRCA-carriers and non-carriers in women 35 years of age or less. Breast 2014, 23, 770-774. [CrossRef] [PubMed]

21. Sun, J.; Meng, H.; Yao, L.; Lv, M.; Bai, J.; Zhang, J.; Wang, L.; Ouyang, T.; Li, J.; Wang, T.; et al. Germline Mutations in Cancer Susceptibility Genes in a Large Series of Unselected Breast Cancer Patients. Clin. Cancer Res. 2017, 23, 6113-6119. [CrossRef]

22. Geredeli, C.; Yasar, N.; Sakin, A. Germline Mutations in BRCA1 and BRCA2 in Breast Cancer Patients with High Genetic Risk in Turkish Population. Int. J. Breast Cancer 2019, 2019, 9645147. [CrossRef]

23. Kemp, Z.; Turnbull, A.; Yost, S.; Seal, S.; Mahamdallie, S.; Poyastro-Pearson, E.; Warren-Perry, M.; Eccleston, A.; Tan, M.-M.; Teo, S.H.; et al. Evaluation of Cancer-Based Criteria for Use in Mainstream BRCA1 and BRCA2 Genetic Testing in Patients with Breast Cancer. JAMA Netw. Open 2019, 2, e194428. [CrossRef]

24. Peto, J.; Mack, T.M. High constant incidence in twins and other relatives of women with breast cancer. Nat. Genet. 2000, 26, 411-414. [CrossRef] [PubMed]

25. Beral, V.; Doll, R.; Peto, R.; Reeves, G. Familial breast cancer: Collaborative reanalysis of individual data from 52 epidemiological studies including 58,209 women with breast cancer and 101,986 women without the disease. Lancet 2001, 358, 1389-1399.

26. Newman, B.; Austin, M.A.; Lee, M.; King, M.-C. Inheritance of human breast cancer: Evidence for autosomal dominant transmission in high-risk families. Proc. Natl. Acad. Sci. USA 1988, 85, 3044-3048. [CrossRef] [PubMed]

27. Lynch, H.T.; Silva, E.; Snyder, C.; Lynch, J.F. Hereditary Breast Cancer: Part I. Diagnosing Hereditary Breast Cancer Syndromes. Breast J. 2008, 14, 3-13. [CrossRef] [PubMed]

28. Hollestelle, A.; Wasielewski, M.; Martens, J.W.; Schutte, M. Discovering moderate-risk breast cancer susceptibility genes. Curr. Opin. Genet. Dev. 2010, 20, 268-276. [CrossRef]

29. The Breast Cancer Susceptibility Collaboration (UK); Renwick, A.; Thompson, D.; Seal, S.; Kelly, P.; Chagtai, T.; Ahmed, M.; North, B.; Jayatilake, H.; Barfoot, R.; et al. ATM mutations that cause ataxia-telangiectasia are breast cancer susceptibility alleles. Nat. Genet. 2006, 38, 873-875. [CrossRef]

30. Sharif, S.; Moran, A.; Huson, S.M.; Iddenden, R.; Shenton, A.; Howard, E.; Evans, D.G.R. Women with neurofibromatosis 1 are at a moderately increased risk of developing breast cancer and should be considered for early screening. J. Med. Genet. 2007, 44, 481-484. [CrossRef]

31. Meijers-Heijboer, H.; Ouweland, A.V.D.; Klijn, J.; Wasielewski, M.; De Snoo, A.; Oldenburg, R.; Hollestelle, A.; Houben, M.; Crepin, E.; Van Veghel-Plandsoen, M.; et al. Low-penetrance susceptibility to breast cancer due to CHEK2*1100delC in noncarriers of BRCA1 or BRCA2 mutations. Nat. Genet. 2002, 31, 55-59. [CrossRef]

32. Dorling, L.; Carvalho, S.; Allen, J.; González-Neira, A.; Luccarini, C.; Wahlström, C.; Pooley, K.A.; Parsons, M.T.; Fortuno, C.; Wang, Q.; et al. Breast Cancer Risk Genes-Association Analysis in More than 113,000 Women. N. Engl. J. Med. 2021, 384, 428-439. [PubMed]

33. Foulkes, W.D. Inherited Susceptibility to Common Cancers. N. Engl. J. Med. 2008, 359, 2143-2153. [CrossRef] [PubMed]

34. Cathcart-Rake, E.J.; Ruddy, K.J.; Johnson, R.H. Modifiable Risk Factors for the Development of Breast Cancer in Young Women. Cancer J. 2018, 24, 275-284. [CrossRef] [PubMed]

35. Hanahan, D.; Weinberg, R.A. Hallmarks of Cancer: The Next Generation. Cell 2011, 144, 646-674. [CrossRef] [PubMed]

36. Knudson, A.G., Jr. Mutation and Cancer: Statistical Study of Retinoblastoma. Proc. Natl. Acad. Sci. USA 1971, 68, 820-823. [CrossRef]

37. Willis, A.; Jung, E.J.; Wakefield, T.; Chen, X. Mutant p53 exerts a dominant negative effect by preventing wild-type p53 from binding to the promoter of its target genes. Oncogene 2004, 23, 2330-2338. [CrossRef]

38. Zhu, G.; Pan, C.; Bei, J.-X.; Li, B.; Liang, C.; Xu, Y.; Fu, X. Mutant p53 in Cancer Progression and Targeted Therapies. Front. Oncol. 2020, 10, 595187. [CrossRef]

39. Olivier, M.; Hollstein, M.; Hainaut, P. TP53 Mutations in Human Cancers: Origins, Consequences, and Clinical Use. Cold Spring Harb. Perspect. Biol. 2010, 2, a001008. [CrossRef]

40. Frebourg, T.; Genturis, T.E.R.N.; Lagercrantz, S.B.; Oliveira, C.; Magenheim, R.; Evans, D.G. Guidelines for the Li-Fraumeni and heritable TP53-related cancer syndromes. Eur. J. Hum. Genet. 2020, 28, 1379-1386. [CrossRef]

41. Schon, K.; Tischkowitz, M. Clinical implications of germline mutations in breast cancer: TP53. Breast Cancer Res. Treat. 2018, 167, 417-423. [CrossRef] 
42. Lee, D.S.; Yoon, S.Y.; Looi, L.M.; Kang, P.; Kang, I.N.; Sivanandan, K.; Ariffin, H.; Thong, M.K.; Chin, K.F.; Mohd Taib, N.A.; et al. Comparable frequency of BRCA1, BRCA2 and TP53 germline mutations in a multi-ethnic Asian cohort suggests TP53 screening should be offered together with BRCA1/2 screening to early-onset breast cancer patients. Breast Cancer Res. 2012, 14, R66. [CrossRef]

43. Mouchawar, J.; Korch, C.; Byers, T.; Pitts, T.M.; Li, E.; McCredie, M.R.; Giles, G.; Hopper, J.L.; Southey, M.C. Population-Based Estimate of the Contribution of TP53 Mutations to Subgroups of Early-Onset Breast Cancer: Australian Breast Cancer Family Study: Table 1. Cancer Res. 2010, 70, 4795-4800. [CrossRef]

44. De Andrade, K.C.; Frone, M.N.; Wegman-Ostrosky, T.; Khincha, P.P.; Kim, J.; Amadou, A.; Santiago, K.M.; Fortes, F.P.; Lemonnier, N.; Mirabello, L.; et al. Variable population prevalence estimates of germline TP53 variants: A gnomAD-based analysis. Hum. Mutat. 2019, 40, 97-105. [CrossRef] [PubMed]

45. Pinto, E.M.; Zambetti, G.P. What 20 years of research has taught us about the TP53 p.R337H mutation. Cancer 2020, 126, 4678-4686. [CrossRef] [PubMed]

46. Bakhuizen, J.J.; Hogervorst, F.B.; Velthuizen, M.E.; Ruijs, M.W.; Van Engelen, K.; Van Os, T.A.; Gille, J.; Collée, M.; Ouweland, A.M.V.D.; Van Asperen, C.J.; et al. TP53 germline mutation testing in early-onset breast cancer: Findings from a nationwide cohort. Fam. Cancer 2019, 18, 273-280. [CrossRef] [PubMed]

47. Ruijs, M.W.G.; Verhoef, S.; Wigbout, G.; Pruntel, R.; Floore, A.N.; De Jong, D.; Veer, L.J.V.; Menko, F.H. Late-Onset Common Cancers in a Kindred with an Arg213Gln TP53 Germline Mutation. Fam. Cancer 2006, 5, 169-174. [CrossRef] [PubMed]

48. Melhem-Bertrandt, A.; Bojadzieva, J.; Ready, K.J.; Obeid, E.; Liu, D.D.; Gutierrez-Barrera, A.M.; Litton, J.K.; Olopade, O.I.; Hortobagyi, G.N.; Strong, L.C.; et al. Early onset HER2-positive breast cancer is associated with germlineTP53mutations. Cancer 2012, 118, 908-913. [CrossRef] [PubMed]

49. Birch, J.M.; Alston, R.D.; McNally, R.; Evans, G.; Kelsey, A.M.; Harris, M.; Eden, O.B.; Varley, J.M. Relative frequency and morphology of cancers in carriers of germline TP53 mutations. Oncogene 2001, 20, 4621-4628. [CrossRef]

50. Network, N.C.C. Genetic/Familial High-Risk Assessement: Breast and Ovarian (Version 3.2019). Available online: https: //www.nccn.org/professionals/physician_gls/pdf/genetics_screening.pdf (accessed on 7 August 2021).

51. Hall, J.M.; Lee, M.K.; Newman, B.; Morrow, J.E.; Anderson, L.A.; Huey, B.; King, M.-C. Linkage of Early-Onset Familial Breast Cancer to Chromosome 17q21. Science 1990, 250, 1684-1689. [CrossRef]

52. Wooster, R.; Neuhausen, S.L.; Mangion, J.; Quirk, Y.; Ford, D.; Collins, N.; Nguyen, K.; Seal, S.; Tran, T.; Averill, D.; et al. Localization of a Breast Cancer Susceptibility Gene, BRCA2, to Chromosome 13q12-13. Science 1994, 265, 2088-2090. [CrossRef]

53. Powell, S.N.; Kachnic, L.A. Roles of BRCA1 and BRCA2 in homologous recombination, DNA replication fidelity and the cellular response to ionizing radiation. Oncogene 2003, 22, 5784-5791. [CrossRef]

54. Yarden, R.I.; Papa, M.Z. BRCA1 at the crossroad of multiple cellular pathways: Approaches for therapeutic interventions. Mol. Cancer Ther. 2006, 5, 1396-1404. [CrossRef]

55. Sharan, S.K.; Morimatsu, M.; Albrecht, U.; Lim, D.-S.; Regel, E.; Dinh, C.; Sands, A.; Eichele, G.; Hasty, P.; Bradley, A. Embryonic lethality and radiation hypersensitivity mediated by Rad51 in mice lacking BRCA2. Nature 1997, 386, 804-810. [CrossRef]

56. Yuan, S.-S.; Lee, S.Y.; Chen, G.; Song, M.; Tomlinson, G.E.; Lee, E.Y. BRCA2 is required for ionizing radiation-induced assembly of Rad51 complex in vivo. Cancer Res. 1999, 59, 3547-3551.

57. Nelson, H.D.; Fu, R.; Goddard, K.; Mitchell, J.P.; Okinaka-Hu, L.; Pappas, M.; Zakher, B.U.S. Preventive Services Task Force Evidence Syntheses, formerly Systematic Evidence Reviews. In Risk Assessment, Genetic Counseling, and Genetic Testing for BRCA-Related Cancer: Systematic Review to Update the U.S. Preventive Services Task Force Recommendation; Agency for Healthcare Research and Quality (US): Rockville, MD, USA, 2013.

58. Thompson, E.R.; Rowley, S.M.; Li, N.; McInerny, S.; Devereux, L.; Wong-Brown, M.W.; Trainer, A.H.; Mitchell, G.; Scott, R.J.; James, P.A.; et al. Panel Testing for Familial Breast Cancer: Calibrating the Tension Between Research and Clinical Care. J. Clin. Oncol. 2016, 34, 1455-1459. [CrossRef]

59. Maxwell, K.N.; Domchek, S.M.; Nathanson, K.L.; Robson, M.E. Population Frequency of Germline BRCA1/2 Mutations. J. Clin. Oncol. 2016, 34, 4183-4185. [CrossRef]

60. Kauff, N. Incidence of non-founder BRCA1 and BRCA2 mutations in high risk Ashkenazi breast and ovarian cancer families. J. Med. Genet. 2002, 39, 611-614. [CrossRef]

61. Nelson, H.D.; Pappas, M.; Zakher, B.; Mitchell, J.P.; Okinaka-Hu, L.; Fu, R. Risk Assessment, Genetic Counseling, and Genetic Testing for BRCA-Related Cancer in Women: A Systematic Review to Update the U.S. Preventive Services Task Force Recommendation. Ann. Intern. Med. 2014, 160, 255-266. [CrossRef] [PubMed]

62. Kuchenbaecker, K.B.; Hopper, J.L.; Barnes, D.; Phillips, K.-A.; Mooij, T.M.; Roos-Blom, M.-J.; Jervis, S.; Van Leeuwen, F.E.; Milne, R.L.; Andrieu, N.; et al. Risks of Breast, Ovarian, and Contralateral Breast Cancer for BRCA1 and BRCA2 Mutation Carriers. JAMA 2017, 317, 2402-2416. [CrossRef] [PubMed]

63. Antoniou, A.; Pharoah, P.; Narod, S.; Risch, H.; Eyfjord, J.; Hopper, J.; Loman, N.; Olsson, H.; Johannsson, O.; Borg, A.; et al. Average Risks of Breast and Ovarian Cancer Associated with BRCA1 or BRCA2 Mutations Detected in Case Series Unselected for Family History: A Combined Analysis of 22 Studies. Am. J. Hum. Genet. 2003, 72, 1117-1130. [CrossRef] [PubMed]

64. Couch, F.J.; Hart, S.N.; Sharma, P.; Toland, A.E.; Wang, X.; Miron, P.; Olson, J.E.; Godwin, A.K.; Pankratz, V.S.; Olswold, C.; et al. Inherited Mutations in 17 Breast Cancer Susceptibility Genes among a Large Triple-Negative Breast Cancer Cohort Unselected for Family History of Breast Cancer. J. Clin. Oncol. 2015, 33, 304-311. [CrossRef] 
65. Buys, S.S.; Sandbach, J.F.; Gammon, A.; Patel, G.; Kidd, J.; Brown, K.L.; Ms, L.S.; Saam, J.; Lancaster, J.; Daly, M.B. A study of over 35,000 women with breast cancer tested with a 25-gene panel of hereditary cancer genes. Cancer 2017, 123, 1721-1730. [CrossRef]

66. Ha, S.M.; Chae, E.Y.; Cha, J.H.; Kim, H.H.; Shin, H.J.; Choi, W.J. Association of BRCA Mutation Types, Imaging Features, and Pathologic Findings in Patients With Breast Cancer With BRCA1 and BRCA2 Mutations. Am. J. Roentgenol. 2017, 209, 920-928. [CrossRef]

67. Brekelmans, C.T.; Tilanus-Linthorst, M.M.; Seynaeve, C.; vd Ouweland, A.; Menke-Pluymers, M.B.; Bartels, C.C.; Kriege, M.; van Geel, A.N.; Burger, C.W.; Eggermont, A.M.; et al. Tumour characteristics, survival and prognostic factors of hereditary breast cancer from BRCA2-, BRCA1- and non-BRCA1/2 families as compared to sporadic breast cancer cases. Eur. J. Cancer 2007, 43, 867-876. [CrossRef]

68. Roukos, D.H. Prognosis of breast cancer in carriers of BRCA1 and BRCA2 mutations. N. Engl. J. Med. 2007, $357,1555$.

69. Musolino, A.; Bella, M.A.; Bortesi, B.; Michiara, M.; Naldi, N.; Zanelli, P.; Capelletti, M.; Pezzuolo, D.; Camisa, R.; Savi, M.; et al. BRCA mutations, molecular markers, and clinical variables in early-onset breast cancer: A population-based study. Breast 2007, 16, 280-292. [CrossRef] [PubMed]

70. Yousef, A.J.A. Male Breast Cancer: Epidemiology and Risk Factors. Semin. Oncol. 2017, 44, 267-272. [CrossRef] [PubMed]

71. Iqbal, J.; Ragone, A.; Lubinski, J.; Lynch, H.T.; Moller, P.; Ghadirian, P.; Foulkes, W.; Armel, S.; Eisen, A.; Neuhausen, S.L.; et al. The incidence of pancreatic cancer in BRCA1 and BRCA2 mutation carriers. Br. J. Cancer 2012, 107, 2005-2009. [CrossRef] [PubMed]

72. Gumaste, P.V.; Penn, L.A.; Cymerman, R.M.; Kirchhoff, T.; Polsky, D.; McLellan, B. Skin cancer risk in BRCA1/2 mutation carriers. Br. J. Dermatol. 2015, 172, 1498-1506. [CrossRef]

73. Daly, M.B.; Pal, T.; Berry, M.P.; Buys, S.S.; Dickson, P.; Domchek, S.M.; Elkhanany, A.; Friedman, S.; Goggins, M.; Hutton, M.L.; et al. Genetic/Familial High-Risk Assessment: Breast, Ovarian, and Pancreatic, Version 2.2021, NCCN Clinical Practice Guidelines in Oncology. J. Natl. Compr. Cancer Netw. 2021, 19, 77-102. [CrossRef]

74. National Institute for Health and Care Excellence: Clinical Guidelines, in Familial Breast Cancer: Classification, Care and Managing Breast Cancer and Related Risks in People with a Family History of Breast Cancer; National Institute for Health and Care Excellence: London, UK, 2019.

75. Heemskerk-Gerritsen, B.A.M.; Jager, A.; Koppert, L.B.; Obdeijn, A.I.-M.; Collée, M.; Meijers-Heijboer, H.E.J.; Jenner, D.J.; Oldenburg, H.S.A.; Van Engelen, K.; De Vries, J.; et al. Survival after bilateral risk-reducing mastectomy in healthy BRCA1 and BRCA2 mutation carriers. Breast Cancer Res. Treat. 2019, 177, 723-733. [CrossRef] [PubMed]

76. Kurian, A.W.; Sigal, B.M.; Plevritis, S.K. Survival analysis of cancer risk reduction strategies for BRCA1/2 mutation carriers. J. Clin. Oncol. 2010, 28, 222-231. [CrossRef]

77. Giannakeas, V.; Narod, S.A. The expected benefit of preventive mastectomy on breast cancer incidence and mortality in BRCA mutation carriers, by age at mastectomy. Breast Cancer Res. Treat. 2018, 167, 263-267. [CrossRef]

78. Metcalfe, K.; Gershman, S.; Ghadirian, P.; Lynch, H.T.; Snyder, C.; Tung, N.; Kim-Sing, C.; Eisen, A.; Foulkes, W.; Rosen, B.; et al. Contralateral mastectomy and survival after breast cancer in carriers of BRCA1 and BRCA2 mutations: Retrospective analysis. BMJ 2014, 348, g226. [CrossRef] [PubMed]

79. Kotsopoulos, J.; Narod, S.A. Prophylactic mastectomy for BRCA mutation carriers after ovarian cancer treatment: Is it beneficial? Expert Rev. Anticancer Ther. 2018, 18, 199-200. [CrossRef]

80. Telli, M.L.; Timms, K.M.; Reid, J.; Hennessy, B.; Mills, G.B.; Jensen, K.C.; Szallasi, Z.; Barry, W.T.; Winer, E.P.; Tung, N.M.; et al. Homologous Recombination Deficiency (HRD) Score Predicts Response to Platinum-Containing Neoadjuvant Chemotherapy in Patients with Triple-Negative Breast Cancer. Clin. Cancer Res. 2016, 22, 3764-3773. [CrossRef]

81. Tutt, A.; Tovey, H.; Cheang, M.C.U.; Kernaghan, S.; Kilburn, L.; Gazinska, P.; Owen, J.; Abraham, J.; Barrett, S.; Barrett-Lee, P.; et al. Carboplatin in BRCA1/2-mutated and triple-negative breast cancer BRCAness subgroups: The TNT Trial. Nat. Med. 2018, 24, 628-637. [CrossRef]

82. Sæther, N.H.; Skuja, E.; Irmejs, A.; Maksimenko, J.; Miklasevics, E.; Purkalne, G.; Gardovskis, J. Platinum-based neoadjuvant chemotherapy in BRCA1-positive breast cancer: A retrospective cohort analysis and literature review. Hered. Cancer Clin. Pract. 2018, 16, 9. [CrossRef] [PubMed]

83. Norquist, B.; Wurz, K.A.; Pennil, C.C.; Garcia, R.; Gross, J.; Sakai, W.; Karlan, B.Y.; Taniguchi, T.; Swisher, E.M. Secondary somatic mutations restoring BRCA1/2 predict chemotherapy resistance in hereditary ovarian carcinomas. J. Clin. Oncol. 2011, 29, 3008-3015. [CrossRef]

84. Fong, P.C.; Boss, D.S.; Yap, T.A.; Tutt, A.; Wu, P.; Mergui-Roelvink, M.; Mortimer, P.; Swaisland, H.; Lau, A.; O'Connor, M.J.; et al. Inhibition of poly(ADP-ribose) polymerase in tumors from BRCA mutation carriers. N. Engl. J. Med. 2009, 361, 123-134. [CrossRef]

85. Balmaña, J.; Tung, N.M.; Isakoff, S.J.; Graña, B.; Ryan, P.D.; Saura, C.; Lowe, E.S.; Frewer, P.; Winer, E.; Baselga, J.; et al. Phase I trial of olaparib in combination with cisplatin for the treatment of patients with advanced breast, ovarian and other solid tumors. Ann. Oncol. 2014, 25, 1656-1663. [CrossRef]

86. Lee, J.-M.; Hays, J.L.; Annunziata, C.M.; Noonan, A.; Minasian, L.; Zujewski, J.A.; Yu, M.; Gordon, N.; Ji, J.; Sissung, T.M.; et al. Phase I/ Ib Study of Olaparib and Carboplatin in BRCA1 or BRCA2 Mutation-Associated Breast or Ovarian Cancer with Biomarker Analyses. J. Natl. Cancer Inst. 2014, 106, dju089. [CrossRef] 
87. Robson, M.; Im, S.-A.; Senkus, E.; Xu, B.; Domchek, S.M.; Masuda, N.; Delaloge, S.; Li, W.; Tung, N.; Armstrong, A.; et al. Olaparib for Metastatic Breast Cancer in Patients with a Germline BRCA Mutation. N. Engl. J. Med. 2017, 377, 523-533. [CrossRef] [PubMed]

88. Tutt, A.N.; Garber, J.E.; Kaufman, B.; Viale, G.; Fumagalli, D.; Rastogi, P.; Gelber, R.D.; de Azambuja, E.; Fielding, A.; Balmaña, J.; et al. Adjuvant Olaparib for Patients with BRCA1- or BRCA2-Mutated Breast Cancer. N. Engl. J. Med. 2021, 384, $2394-2405$. [CrossRef] [PubMed]

89. Zhang, D.; Singh, B.; Moerland, J.; Mitchell, O.; Lockwood, L.; Carapellucci, S.; Sridhar, S.; Liby, K.T. Sustained, local delivery of the PARP inhibitor talazoparib prevents the development of mammary gland hyperplasia in BRCA1-deficient mice. Sci. Rep. 2021, 11, 1234. [CrossRef] [PubMed]

90. To, C.; Kim, E.-H.; Royce, D.B.; Williams, C.R.; Collins, R.M.; Risingsong, R.; Sporn, M.B.; Liby, K.T. The PARP Inhibitors, Veliparib and Olaparib, Are Effective Chemopreventive Agents for Delaying Mammary Tumor Development in BRCA1-deficient Mice. Cancer Prev. Res. 2014, 7, 698-707. [CrossRef] [PubMed]

91. To, C.; Sporn, M.B.; Liby, K.T. PARP inhibitors for chemoprevention-Reply. Cancer Prev. Res. 2014, 7, 1172. [CrossRef] [PubMed]

92. Chand, S.N.; Blanco, F.F.; Jimbo, M.; Tsangaris, T.N.; Cristofanilli, M.; Yeo, C.J.; Winter, J.M.; Pishvaian, M.J.; Brody, J.R. PARP Inhibitors for Chemoprevention-Letter. Cancer Prev. Res. 2014, 7, 1170-1171. [CrossRef]

93. Cuzick, J.; Sestak, I.; Bonanni, B.; Costantino, J.P.; Cummings, S.; DeCensi, A.; Dowsett, M.; Forbes, J.F.; Ford, L.; LaCroix, A.Z.; et al. Selective oestrogen receptor modulators in prevention of breast cancer: An updated meta-analysis of individual participant data. Lancet 2013, 381, 1827-1834. [CrossRef]

94. King, M.C.; Wieand, S.; Hale, K.; Lee, M.; Walsh, T.; Owens, K.; Tait, J.; Ford, L.; Dunn, B.K.; Costantino, J.; et al. Tamoxifen and breast cancer incidence among women with inherited mutations in BRCA1 and BRCA2: National Surgical Adjuvant Breast and Bowel Project (NSABP-P1) Breast Cancer Prevention Trial. JAMA 2001, 286, 2251-2256. [CrossRef]

95. Singer, C.F. Nonsurgical Prevention Strategies in BRCA1 and BRCA2 Mutation Carriers. Breast Care 2021, 16, 144-148. [CrossRef]

96. Rosenthal, A.N.; Fraser, L.; Manchanda, R.; Badman, P.; Philpott, S.; Mozersky, J.; Hadwin, R.; Cafferty, F.; Benjamin, E.; Singh, N.; et al. Results of Annual Screening in Phase I of the United Kingdom Familial Ovarian Cancer Screening Study Highlight the Need for Strict Adherence to Screening Schedule. J. Clin. Oncol. 2013, 31, 49-57. [CrossRef]

97. Rosenthal, A.N.; Fraser, L.S.; Philpott, S.; Manchanda, R.; Burnell, M.; Badman, P.; Hadwin, R.; Rizzuto, I.; Benjamin, E.; Singh, N.; et al. Evidence of Stage Shift in Women Diagnosed with Ovarian Cancer during Phase II of the United Kingdom Familial Ovarian Cancer Screening Study. J. Clin. Oncol. 2017, 35, 1411-1420. [CrossRef]

98. Mavaddat, N.; Antoniou, A.C.; Mooij, T.M.; Hooning, M.J.; Heemskerk-Gerritsen, B.A.; Noguès, C.; Gauthier-Villars, M.; Caron, O.; Gesta, P.; Pujol, P.; et al. Risk-reducing salpingo-oophorectomy, natural menopause, and breast cancer risk: An international prospective cohort of BRCA1 and BRCA2 mutation carriers. Breast Cancer Res. 2020, 22, 8. [CrossRef]

99. Kotsopoulos, J.; Huzarski, T.; Gronwald, J.; Singer, C.F.; Moller, P.; Lynch, H.T.; Armel, S.; Karlan, B.; Foulkes, W.D.; Neuhausen, S.L.; et al. Bilateral Oophorectomy and Breast Cancer Risk in BRCA1 and BRCA2 Mutation Carriers. J. Natl. Cancer Inst. 2017, 109. [CrossRef] [PubMed]

100. Zhang, F.; Fan, Q.; Ren, K.; Andreassen, P.R. PALB2 Functionally Connects the Breast Cancer Susceptibility Proteins BRCA1 and BRCA2. Mol. Cancer Res. 2009, 7, 1110-1118. [CrossRef]

101. Rahman, N.; The Breast Cancer Susceptibility Collaboration (UK); Seal, S.; Thompson, D.; Kelly, P.; Renwick, A.; Elliott, A.; Reid, S.; Spanova, K.; Barfoot, R.; et al. PALB2, which encodes a BRCA2-interacting protein, is a breast cancer susceptibility gene. Nat. Genet. 2007, 39, 165-167. [CrossRef] [PubMed]

102. Antoniou, A.C.; Casadei, S.; Heikkinen, T.; Barrowdale, D.; Pylkäs, K.; Roberts, J.; Lee, A.; Subramanian, D.; De Leeneer, K.; Fostira, F.; et al. Breast-Cancer Risk in Families with Mutations in PALB2. N. Engl. J. Med. 2014, 371, 497-506. [CrossRef] [PubMed]

103. Kraus, C.; Hoyer, J.; Vasileiou, G.; Wunderle, M.; Lux, M.P.; Fasching, P.A.; Krumbiegel, M.; Uebe, S.; Reuter, M.; Beckmann, M.W.; et al. Gene panel sequencing in familial breast/ovarian cancer patients identifies multiple novel mutations also in genes others than BRCA1/2. Int. J. Cancer 2017, 140, 95-102. [CrossRef]

104. Taylor, A.; Brady, A.F.; Frayling, I.; Hanson, H.; Tischkowitz, M.; Turnbull, C.; Side, L. Consensus for genes to be included on cancer panel tests offered by UK genetics services: Guidelines of the UK Cancer Genetics Group. J. Med. Genet. 2018, 55, 372-377. [CrossRef]

105. Yang, X.; Leslie, G.; Doroszuk, A.; Schneider, S.; Allen, J.; Decker, B.; Dunning, A.M.; Redman, J.; Scarth, J.; Plaskocinska, I.; et al. Cancer Risks Associated with Germline PALB2 Pathogenic Variants: An International Study of 524 Families. J. Clin. Oncol. 2020, 38, 674-685. [CrossRef] [PubMed]

106. Tischkowitz, M.; Balmaña, J.; Foulkes, W.D.; James, P.; Ngeow, J.; Schmutzler, R.; Voian, N.; Wick, M.J.; Stewart, D.R.; Pal, T.; et al. Management of individuals with germline variants in PALB2: A clinical practice resource of the American College of Medical Genetics and Genomics (ACMG). Genet. Med. 2021, 23, 1416-1423. [CrossRef] [PubMed]

107. Li, A.; Geyer, F.C.; Blecua, P.; Lee, J.Y.; Selenica, P.; Brown, D.N.; Pareja, F.; Lee, S.S.K.; Kumar, R.; Rivera, B.; et al. Homologous recombination DNA repair defects in PALB2-associated breast cancers. NPJ Breast Cancer 2019, 5, 23. [CrossRef] [PubMed]

108. Suszynska, M.; Ratajska, M.; Kozlowski, P. BRIP1, RAD51C, and RAD51D mutations are associated with high susceptibility to ovarian cancer: Mutation prevalence and precise risk estimates based on a pooled analysis of $\sim 30,000$ cases. J. Ovarian Res. 2020, 13, 50. [CrossRef] 
109. Yang, X.; Song, H.; Leslie, G.; Engel, C.; Hahnen, E.; Auber, B.; Horváth, J.; Kast, K.; Niederacher, D.; Turnbull, C.; et al. Ovarian and Breast Cancer Risks Associated with Pathogenic Variants in RAD51C and RAD51D. J. Natl. Cancer Inst. 2020, 112, 1242-1250. [CrossRef]

110. Shimelis, H.; LaDuca, H.; Hu, C.; Hart, S.N.; Na, J.; Thomas, A.; Akinhanmi, M.; Moore, R.M.; Brauch, H.; Cox, A.; et al. Triple-Negative Breast Cancer Risk Genes Identified by Multigene Hereditary Cancer Panel Testing. J. Natl. Cancer Inst. 2018, 110, 855-862. [CrossRef] [PubMed]

111. Li, N.; McInerny, S.; Zethoven, M.; Cheasley, D.; Lim, B.W.X.; Rowley, S.M.; Devereux, L.; Grewal, N.; Ahmadloo, S.; Byrne, D.; et al. Combined Tumor Sequencing and Case-Control Analyses of RAD51C in Breast Cancer. J. Natl. Cancer Inst. 2019, 111, 1332-1338. [CrossRef]

112. Castella, M.; Jacquemont, C.; Thompson, E.L.; Yeo, J.E.; Cheung, R.S.; Huang, J.-W.; Sobeck, A.; Hendrickson, E.A.; Taniguchi, T. FANCI Regulates Recruitment of the FA Core Complex at Sites of DNA Damage Independently of FANCD2. PLoS Genet. 2015, 11, e1005563. [CrossRef]

113. Sawyer, S.L.; Tian, L.; Kähkönen, M.; Schwartzentruber, J.; Kircher, M.; Majewski, J.; Dyment, D.A.; Innes, A.M.; Boycott, K.M.; Moreau, L.A.; et al. Biallelic Mutations in BRCA1 Cause a New Fanconi Anemia Subtype. Cancer Discov. 2015, 5, 135-142. [CrossRef]

114. Keupp, K.; Hampp, S.; Hübbel, A.; Maringa, M.; Kostezka, S.; Rhiem, K.; Waha, A.; Wappenschmidt, B.; Pujol, R.; Surrallés, J.; et al. Biallelic germline BRCA1 mutations in a patient with early onset breast cancer, mild Fanconi anemia-like phenotype, and no chromosome fragility. Mol. Genet. Genom. Med. 2019, 7, e863. [CrossRef]

115. Kwong, A.; Ho, C.; Shin, V.; Au, C.; Chan, T.; Ma, E. A Case Report of Germline Compound Heterozygous Mutations in the BRCA1 Gene of an Ovarian and Breast Cancer Patient. Int. J. Mol. Sci. 2021, 22, 889. [CrossRef]

116. Chirita-Emandi, A.; Andreescu, N.; Popa, C.; Mihailescu, A.; Riza, A.-L.; Plesea, R.; Ioana, M.; Arghirescu, S.; Puiu, M. Biallelic variants in $B R C A 1$ gene cause a recognisable phenotype within chromosomal instability syndromes reframed as $B R C A 1$ deficiency. J. Med. Genet. 2021, 58, 648-652. [CrossRef]

117. Oostra, A.B.; Nieuwint, A.W.M.; Joenje, H.; De Winter, J.P. Diagnosis of Fanconi Anemia: Chromosomal Breakage Analysis. Anemia 2012, 2012, 238731. [CrossRef]

118. Fanconi Anemia Research Fund. Fanconi Anemia Clinical Care Guidelines. 2020. Available online: www.fanconi.org (accessed on 4 October 2021).

119. Shimelis, H.; Mesman, R.; Von Nicolai, C.; Ehlen, A.; Guidugli, L.; Martin, C.; Calléja, F.M.; Meeks, H.; Hallberg, E.; Hinton, J.; et al. BRCA2 Hypomorphic Missense Variants Confer Moderate Risks of Breast Cancer. Cancer Res. 2017, 77, 2789-2799. [CrossRef] [PubMed]

120. Zhang, N.; Chen, P.; Khanna, K.K.; Scott, S.; Gatei, M.; Kozlov, S.; Watters, D.; Spring, K.; Yen, T.; Lavin, M.F. Isolation of full-length ATM cDNA and correction of the ataxia-telangiectasia cellular phenotype. Proc. Natl. Acad. Sci. USA 1997, 94, 8021-8026. [CrossRef] [PubMed]

121. Lavin, M.; Khana, K.K.; Beamish, H.; Spring, K.; Watters, D.; Shiloh, Y. Relationship of the ataxia-telangiectasia protein ATM to phosphoinositide 3-kinase. Trends Biochem. Sci. 1995, 20, 382-383. [CrossRef]

122. Yanofsky, R.A.; Seshia, S.S.; Dawson, A.J.; Stobart, K.; Greenberg, C.R.; Booth, F.A.; Prasad, C.; Del Bigio, M.; Wrogemann, J.J.; Fike, F.; et al. Ataxia-Telangiectasia: Atypical Presentation and Toxicity of Cancer Treatment. Can. J. Neurol. Sci. 2009, 36, 462-467. [CrossRef]

123. Saunders-Pullman, R.; Raymond, D.; Stoessl, A.J.; Hobson, D.; Nakamura, T.; Pullman, S.; Lefton, D.; Okun, M.S.; Uitti, R.; Sachdev, R.; et al. Variant ataxia-telangiectasia presenting as primary-appearing dystonia in Canadian Mennonites. Neurology 2012, 78, 649-657. [CrossRef] [PubMed]

124. Nakamura, K.; Fike, F.; Haghayegh, S.; Saunders-Pullman, R.; Dawson, A.J.; Dörk, T.; Gatti, R.A. A-T Winnipeg: Pathogenesis of rare ATM missense mutation c.6200C $>$ A with decreased protein expression and downstream signaling, early-onset dystonia, cancer, and life-threatening radiotoxicity. Mol. Genet. Genom. Med. 2014, 2, 332-340. [CrossRef] [PubMed]

125. Tavtigian, S.V.; Oefner, P.J.; Babikyan, D.; Hartmann, A.; Healey, S.; Le Calvez-Kelm, F.; Lesueur, F.; Byrnes, G.; Chuang, S.-C.; Forey, N.; et al. Rare, Evolutionarily Unlikely Missense Substitutions in ATM Confer Increased Risk of Breast Cancer. Am. J. Hum. Genet. 2009, 85, 427-446. [CrossRef]

126. Thompson, D.; Duedal, S.; Kirner, J.; McGuffog, L.; Last, J.; Reiman, A.; Byrd, P.; Taylor, M.; Easton, D.F. Cancer Risks and Mortality in Heterozygous ATM Mutation Carriers. J. Natl. Cancer Inst. 2005, 97, 813-822. [CrossRef]

127. Chenevix-Trench, G.; Spurdle, A.; Terry, M.B.; Daly, M.; Buys, S.; Southey, M.; Andrulis, I.; John, E.; Khanna, K.K.; Hopper, J.; et al. Rare variants in the ATM gene and risk of breast cancer. Breast Cancer Res. 2011, 13, R73. [CrossRef]

128. Schutte, M.; Seal, S.; Barfoot, R.; Meijers-Heijboer, H.; Wasielewski, M.; Evans, G.; Eccles, D.M.; Meijers, C.; Lohman, F.; Klijn, J.; et al. Variants in CHEK2 Other than 1100delC Do Not Make a Major Contribution to Breast Cancer Susceptibility. Am. J. Hum. Genet. 2003, 72, 1023-1028. [CrossRef]

129. Nevanlinna, H.; Bartek, J. The CHEK2 gene and inherited breast cancer susceptibility. Oncogene 2006, 25, 5912-5919. [CrossRef]

130. Schmidt, M.; Hogervorst, F.; van Hien, R.; Cornelissen, S.; Broeks, A.; Adank, M.; Meijers, H.; Waisfisz, Q.; Hollestelle, A.; Schutte, M.; et al. Age- and Tumor Subtype-Specific Breast Cancer Risk Estimates for CHEK2*1100delC Carriers. J. Clin. Oncol. 2016, 34, 2750-2760. [CrossRef] 
131. Vahteristo, P.; Bartkova, J.; Eerola, H.; Syrjäkoski, K.; Ojala, S.; Kilpivaara, O.; Tamminen, A.; Kononen, J.; Aittomäki, K.; Heikkilä, P.; et al. A CHEK2 Genetic Variant Contributing to a Substantial Fraction of Familial Breast Cancer. Am. J. Hum. Genet. 2002, 71, 432-438. [CrossRef] [PubMed]

132. Muranen, T.A.; Blomqvist, C.; Dörk, T.; Jakubowska, A.; Heikkilä, P.; Fagerholm, R.; Greco, D.; Aittomäki, K.; Bojesen, S.E.; Shah, M.; et al. Patient survival and tumor characteristics associated with CHEK2:p.I157T_Findings from the Breast Cancer Association Consortium. Breast Cancer Res. 2016, 18, 98. [CrossRef]

133. Greville-Heygate, S.L.; Maishman, T.; Tapper, W.J.; Cutress, R.I.; Copson, E.; Dunning, A.M.; Haywood, L.; Jones, L.J.; Eccles, D.M. Pathogenic Variants in CHEK2 Are Associated with an Adverse Prognosis in Symptomatic Early-Onset Breast Cancer. JCO Precis. Oncol. 2020, 472-485. [CrossRef]

134. Schmidt, M.K.; Tollenaar, R.A.; de Kemp, S.R.; Broeks, A.; Cornelisse, C.J.; Smit, V.T.; Peterse, J.L.; van Leeuwen, F.E.; Veer, L.J.V. Breast Cancer Survival and Tumor Characteristics in Premenopausal Women Carrying the CHEK2*1100delC Germline Mutation. J. Clin. Oncol. 2007, 26, 64-69. [CrossRef] [PubMed]

135. Muranen, T.A.; Greco, D.; Blomqvist, C.; Aittomäki, K.; Khan, S.; Hogervorst, F.; Verhoef, S.; Pharoah, P.D.P.; Dunning, A.M.; Shah, M.; et al. Genetic modifiers of CHEK2*1100delC-associated breast cancer risk. Genet. Med. 2017, 19, 599-603. [CrossRef] [PubMed]

136. Huijts, P.E.; Hollestelle, A.; Balliu, B.; Houwing-Duistermaat, J.J.; Meijers, C.M.; Blom, J.C.; Ozturk, B.; Krol-Warmerdam, E.M.; Wijnen, J.; Berns, E.M.; et al. CHEK2*1100delC homozygosity in the Netherlands-Prevalence and risk of breast and lung cancer. Eur. J. Hum. Genet. 2014, 22, 46-51. [CrossRef]

137. Rainville, I.; Hatcher, S.; Rosenthal, E.; Larson, K.; Bernhisel, R.; Meek, S.; Gorringe, H.; Mundt, E.; Manley, S. High risk of breast cancer in women with biallelic pathogenic variants in CHEK2. Breast Cancer Res. Treat. 2020, 180, 503-509. [CrossRef]

138. Xia, Y.; Pao, G.M.; Chen, H.-W.; Verma, I.M.; Hunter, T. Enhancement of BRCA1 E3 Ubiquitin Ligase Activity through Direct Interaction with the BARD1 Protein. J. Biol. Chem. 2003, 278, 5255-5263. [CrossRef]

139. Chen, A.; Kleiman, F.E.; Manley, J.L.; Ouchi, T.; Pan, Z.-Q. Autoubiquitination of the BRCA1·BARD1 RING Ubiquitin Ligase. J. Biol. Chem. 2002, 277, 22085-22092. [CrossRef]

140. Wendt, C.; Margolin, S. Identifying breast cancer susceptibility genes-A review of the genetic background in familial breast cancer. Acta Oncol. 2019, 58, 135-146. [CrossRef] [PubMed]

141. Tan, M.-H.; Mester, J.L.; Ngeow, J.; Rybicki, L.A.; Orloff, M.S.; Eng, C. Lifetime Cancer Risks in Individuals with Germline PTEN Mutations. Clin. Cancer Res. 2012, 18, 400-407. [CrossRef]

142. Hearle, N.; Schumacher, V.; Menko, F.H.; Olschwang, S.; Boardman, L.A.; Gille, J.; Keller, J.J.; Westerman, A.M.; Scott, R.J.; Lim, W.; et al. Frequency and Spectrum of Cancers in the Peutz-Jeghers Syndrome. Clin. Cancer Res. 2006, 12, 3209-3215. [CrossRef]

143. Li, J.; Yen, C.; Liaw, D.; Podsypanina, K.; Bose, S.; Wang, S.I.; Puc, J.; Miliaresis, C.; Rodgers, L.; McCombie, R.; et al. PTEN, a Putative Protein Tyrosine Phosphatase Gene Mutated in Human Brain, Breast, and Prostate Cancer. Science 1997, 275, $1943-1947$. [CrossRef] [PubMed]

144. Liaw, D.; Marsh, D.J.; Li, J.; Dahia, P.L.M.; Wang, S.I.; Zheng, Z.; Bose, S.; Call, K.M.; Tsou, H.C.; Peacoke, M.; et al. Germline mutations of the PTEN gene in Cowden disease, an inherited breast and thyroid cancer syndrome. Nat. Genet. 1997, 16, 64-67. [CrossRef]

145. Marsh, D.J.; Dahia, P.L.M.; Zheng, Z.; Liaw, D.; Parsons, R.; Gorlin, R.J.; Eng, C. Germline mutations in PTEN are present in Bannayan-Zonana syndrome. Nat. Genet. 1997, 16, 333-334. [CrossRef] [PubMed]

146. Zhou, X.-P.; Hampel, H.; Thiele, H.; Gorlin, R.J.; Hennekam, R.C.; Parisi, M.; Winter, R.M.; Eng, C. Association of germline mutation in the PTEN tumour suppressor gene and Proteus and Proteus-like syndromes. Lancet 2001, 358, 210-211. [CrossRef]

147. Lee, Y.-R.; Chen, M.; Pandolfi, P.P. The functions and regulation of the PTEN tumour suppressor: New modes and prospects. Nat. Rev. Mol. Cell Biol. 2018, 19, 547-562. [CrossRef]

148. Tan, M.-H.; Mester, J.; Peterson, C.; Yang, Y.; Chen, J.-L.; Rybicki, L.A.; Milas, K.; Pederson, H.; Remzi, B.; Orloff, M.S.; et al. A Clinical Scoring System for Selection of Patients for PTEN Mutation Testing Is Proposed on the Basis of a Prospective Study of 3042 Probands. Am. J. Hum. Genet. 2011, 88, 42-56. [CrossRef] [PubMed]

149. Macken, W.L.; Tischkowitz, M.; Lachlan, K.L. PTEN Hamartoma tumor syndrome in childhood: A review of the clinical literature. Am. J. Med. Genet. C Semin. Med. Genet. 2019, 181, 591-610. [CrossRef] [PubMed]

150. Tischkowitz, M.; Colas, C.; Pouwels, S.; Hoogerbrugge, N. Cancer Surveillance Guideline for individuals with PTEN hamartoma tumour syndrome. Eur. J. Hum. Genet. 2020, 28, 1387-1393. [CrossRef] [PubMed]

151. Daniell, J.; Plazzer, J.-P.; Perera, A.; Macrae, F. An exploration of genotype-phenotype link between Peutz-Jeghers syndrome and STK11: A review. Fam. Cancer 2018, 17, 421-427. [CrossRef]

152. Korsse, S.E.; Harinck, F.; van Lier, M.G.; Biermann, K.; Offerhaus, G.J.A.; Krak, N.; Looman, C.W.; van Veelen, W.; Kuipers, E.J.; Wagner, A.; et al. Pancreatic cancer risk in Peutz-Jeghers syndrome patients: A large cohort study and implications for surveillance. J. Med. Genet. 2013, 50, 59-64. [CrossRef] [PubMed]

153. Beggs, A.D.; Latchford, A.R.; Vasen, H.F.A.; Moslein, G.; Alonso, A.; Aretz, S.; Bertario, L.; Blanco, I.; Bulow, S.; Burn, J.; et al. Peutz-Jeghers syndrome: A systematic review and recommendations for management. Gut 2010, 59, 975-986. [CrossRef]

154. Garg, K.; Karnezis, A.N.; Rabban, J.T. Uncommon hereditary gynaecological tumour syndromes: Pathological features in tumours that may predict risk for a germline mutation. Pathology 2018, 50, 238-256. [CrossRef] 
155. Takeichi, M.; Hirano, S.; Matsuyoshi, N.; Fujimori, T. Cytoplasmic Control of Cadherin-mediated Cell-Cell Adhesion. Cold Spring Harb. Symp. Quant. Biol. 1992, 57, 327-334. [CrossRef]

156. Christofori, G.; Semb, H. The role of the cell-adhesion molecule E-cadherin as a tumour-suppressor gene. Trends Biochem. Sci. 1999, 24, 73-76. [CrossRef]

157. Blair, V.R.; McLeod, M.; Carneiro, F.; Coit, D.G.; D’Addario, J.L.; van Dieren, J.M.; Harris, K.L.; Hoogerbrugge, N.; Oliveira, C.; van der Post, R.S.; et al. Hereditary diffuse gastric cancer: Updated clinical practice guidelines. Lancet Oncol. 2020, 21, e386-e397. [CrossRef]

158. Petridis, C.; Shinomiya, I.; Kohut, K.; Gorman, P.; Caneppele, M.; Shah, V.; Troy, M.; Pinder, S.E.; Hanby, A.; Tomlinson, I.; et al. Germline CDH1 mutations in bilateral lobular carcinoma in situ. Br. J. Cancer 2014, 110, 1053-1057. [CrossRef]

159. Benusiglio, P.R.; Malka, D.; Rouleau, E.; De Pauw, A.; Buecher, B.; Noguès, C.; Fourme, E.; Colas, C.; Coulet, F.; Warcoin, M.; et al. CDH1germline mutations and the hereditary diffuse gastric and lobular breast cancer syndrome: A multicentre study. J. Med. Genet. 2013, 50, 486-489. [CrossRef]

160. Masciari, S.; Larsson, N.; Senz, J.; Boyd, N.; Kaurah, P.; Kandel, M.J.; Harris, L.N.; Pinheiro, H.C.; Troussard, A.; Miron, P.; et al. Germline E-cadherin mutations in familial lobular breast cancer. J. Med. Genet. 2007, 44, 726-731. [CrossRef]

161. Petridis, C.; Arora, I.; Shah, V.; Moss, C.L.; Mera, A.; Clifford, A.; Gillett, C.; Pinder, S.E.; Tomlinson, I.; Roylance, R.; et al. Frequency of Pathogenic Germline Variants in CDH1, BRCA2, CHEK2, PALB2, BRCA1, and TP53 in Sporadic Lobular Breast Cancer. Cancer Epidemiol. Biomark. Prev. 2019, 28, 1162-1168. [CrossRef]

162. Xie, Z.M.; Li, L.S.; Laquet, C.; Xie, X.M.; Penault-Llorca, F.; Uhrhammer, N.; Bignon, Y.J. Germline mutations of the E-cadherin gene in families with inherited invasive lobular breast carcinoma but no diffuse gastric cancer. Cancer 2011, 117, 3112-3117. [CrossRef] [PubMed]

163. Rousset-Jablonski, C.; Gompel, A. Screening for familial cancer risk: Focus on breast cancer. Maturitas 2017, 105, 69-77. [CrossRef]

164. Van der Post, R.S.; Vogelaar, I.P.; Carneiro, F.; Guilford, P.; Huntsman, D.; Hoogerbrugge, N.; Caldas, C.; Schreiber, K.E.; Hardwick, R.H.; Ausems, M.G.; et al. Hereditary diffuse gastric cancer: Updated clinical guidelines with an emphasis on germline CDH1 mutation carriers. J. Med. Genet. 2015, 52, 361-374. [CrossRef] [PubMed]

165. Ghoumid, J.; Stichelbout, M.; Jourdain, A.-S.; Frenois, F.; Lejeune-Dumoulin, S.; Alex-Cordier, M.-P.; Lebrun, M.; Guerreschi, P.; Duquennoy-Martinot, V.; Vinchon, M.; et al. Blepharocheilodontic syndrome is a CDH1 pathway-related disorder due to mutations in CDH1 and CTNND1. Genet. Med. 2017, 19, 1013-1021. [CrossRef] [PubMed]

166. Leblanc, S.; Naveen, D.; Haan, E.; Barnett, C.; Rawlings, L.; Roscioli, T.; Poplawski, N. CDH1-related blepharocheilodontic syndrome is associated with diffuse gastric cancer risk. Am. J. Med. Genet. Part A 2020, 182, 1780-1784. [CrossRef] [PubMed]

167. Evans, D.; Howard, E.; Giblin, C.; Clancy, T.; Spencer, H.; Huson, S.; Lalloo, F. Birth incidence and prevalence of tumor-prone syndromes: Estimates from a UK family genetic register service. Am. J. Med. Genet. Part A 2010, 152A, 327-332. [CrossRef]

168. Klose, A.; Ahmadian, M.R.; Schuelke, M.; Scheffzek, K.; Hoffmeyer, S.; Gewies, A.; Schmitz, F.; Kaufmann, D.; Peters, H.; Wittinghofer, A.; et al. Selective disactivation of neurofibromin GAP activity in neurofibromatosis type 1. Hum. Mol. Genet. 1998, 7, 1261-1268. [CrossRef] [PubMed]

169. Seminog, O.O.; Goldacre, M.J. Age-specific risk of breast cancer in women with neurofibromatosis type 1. Br. J. Cancer 2015, 112, 1546-1548. [CrossRef] [PubMed]

170. Howell, S.J.; Hockenhull, K.; Salih, Z.; Evans, D.G. Increased risk of breast cancer in neurofibromatosis type 1: Current insights. Breast Cancer 2017, 9, 531-536. [CrossRef]

171. Legius, E.; Messiaen, L.; Wolkenstein, P.; Pancza, P.; Avery, R.A.; Berman, Y.; Blakeley, J.; Babovic-Vuksanovic, D.; Cunha, K.S.; Ferner, R.; et al. Revised diagnostic criteria for neurofibromatosis type 1 and Legius syndrome: An international consensus recommendation. Genet. Med. 2021, 23, 1506-1513. [CrossRef] [PubMed]

172. Grolleman, J.E.; de Voer, R.M.; Elsayed, F.A.; Nielsen, M.; Weren, R.D.; Palles, C.; Ligtenberg, M.J.; Vos, J.R.; Broeke, S.W.T.; de Miranda, N.; et al. Mutational Signature Analysis Reveals NTHL1 Deficiency to Cause a Multi-tumor Phenotype. Cancer Cell 2019, 35, 256-266.e5. [CrossRef] [PubMed]

173. Michailidou, K.; Collaborators, N.; Lindström, S.; Dennis, J.; Beesley, J.; Hui, S.; Kar, S.P.; Lemaçon, A.; Soucy, P.; Glubb, D.; et al. Association analysis identifies 65 new breast cancer risk loci. Nature 2017, 551, 92-94. [CrossRef] [PubMed]

174. Buniello, A.; MacArthur, J.A.L.; Cerezo, M.; Harris, L.W.; Hayhurst, J.; Malangone, C.; McMahon, A.; Morales, J.; Mountjoy, E.; Sollis, E.; et al. The NHGRI-EBI GWAS Catalog of published genome-wide association studies, targeted arrays and summary statistics 2019. Nucleic Acids Res. 2019, 47, D1005-D1012. [CrossRef]

175. Mavaddat, N.; Michailidou, K.; Dennis, J.; Lush, M.; Fachal, L.; Lee, A.; Tyrer, J.P.; Chen, T.H.; Wang, Q.; Bolla, M.K.; et al. Polygenic Risk Scores for Prediction of Breast Cancer and Breast Cancer Subtypes. Am. J. Hum. Genet. 2019, 104, 21-34. [CrossRef]

176. Läll, K.; Lepamets, M.; Palover, M.; Esko, T.; Metspalu, A.; Tõnisson, N.; Padrik, P.; Mägi, R.; Fischer, K. Polygenic prediction of breast cancer: Comparison of genetic predictors and implications for risk stratification. BMC Cancer 2019, 19, 557. [CrossRef] [PubMed]

177. Lambert, S.A.; Abraham, G.; Inouye, M. Towards clinical utility of polygenic risk scores. Hum. Mol. Genet. 2019, 28 , R133-R142. [CrossRef]

178. Shieh, Y.; Hu, D.; Ma, L.; Huntsman, S.; Gard, C.C.; Leung, J.W.T.; Tice, J.; Vachon, C.M.; Cummings, S.R.; Kerlikowske, K.; et al. Breast cancer risk prediction using a clinical risk model and polygenic risk score. Breast Cancer Res. Treat. 2016, 159, 513-525. [CrossRef] 
179. Li, H.; Feng, B.; Miron, A.; Chen, X.; Beesley, J.; Bimeh, E.; Barrowdale, D.; John, E.M.; Daly, M.B.; Andrulis, I.L.; et al. Breast cancer risk prediction using a polygenic risk score in the familial setting: A prospective study from the Breast Cancer Family Registry and kConFab. Genet. Med. 2017, 19, 30-35. [CrossRef] [PubMed]

180. Kolak, A.; Kamińska, M.; Sygit, K.; Budny, A.; Surdyka, D.; Kukiełka-Budny, B.; Burdan, F. Primary and secondary prevention of breast cancer. Ann. Agric. Environ. Med. 2017, 24, 549-553. [CrossRef]

181. Howell, A.; Anderson, A.S.; Clarke, R.B.; Duffy, S.W.; Evans, D.G.; Garcia-Closas, M.; Gescher, A.J.; Key, T.J.; Saxton, J.M.; Harvie, M.N. Risk determination and prevention of breast cancer. Breast Cancer Res. 2014, 16, 446. [CrossRef]

182. Coughlin, S.S.; Smith, S.A. The Impact of the Natural, Social, Built, and Policy Environments on Breast Cancer. J. Environ. Health Sci. 2015, 1.

183. Daniels, K.; Abma, J.C. Current Contraceptive Status among Women Aged 15-49: United States, 2017-2019. NCHS Data Brief 2020, 388, 1-8.

184. Calle, E.; Heath, C.; MiracleMcMahill, H.; Coates, R.; Liff, J.; Franceschi, S.; Talamini, R.; Chantarakul, N.; Koetsawang, S.; Rachawat, D.; et al. Breast cancer and hormonal contraceptives: Collaborative reanalysis of individual data on 53,297 women with breast cancer and 100,239 women without breast cancer from 54 epidemiological studies. Lancet 1996, 347, 1713-1727. [CrossRef]

185. Schneyer, R.; Lerma, K. Health outcomes associated with use of hormonal contraception: Breast cancer. Curr. Opin. Obstet. Gynecol. 2018, 30, 414-418. [CrossRef]

186. Mørch, L.S.; Skovlund, C.W.; Hannaford, P.C.; Iversen, L.; Fielding, S.; Lidegaard, Ø. Contemporary Hormonal Contraception and the Risk of Breast Cancer. N. Engl. J. Med. 2017, 377, 2228-2239. [CrossRef] [PubMed]

187. Gierisch, J.M.; Coeytaux, R.R.; Urrutia, R.P.; Havrilesky, L.J.; Moorman, P.G.; Lowery, W.J.; Dinan, M.; McBroom, A.J.; Hasselblad, V.; Sanders, G.D.; et al. Oral contraceptive use and risk of breast, cervical, colorectal, and endometrial cancers: A systematic review. Cancer Epidemiol. Biomark. Prev. 2013, 22, 1931-1943. [CrossRef] [PubMed]

188. Bassuk, S.S.; Manson, J.E. Oral contraceptives and menopausal hormone therapy: Relative and attributable risks of cardiovascular disease, cancer, and other health outcomes. Ann. Epidemiol. 2015, 25, 193-200. [CrossRef]

189. Dorchak, J.A.; Maria, S.; Guarinoni, J.L.; Duensing, A.; Somiari, S.; Cavanaugh, J.; Deyarmin, B.; Hu, H.; Iida, J.; Shriver, C.D.; et al. The Impact of Hormonal Contraceptives on Breast Cancer Pathology. Horm. Cancer 2018, 9, 240-253. [CrossRef]

190. Barriga, P.; Vanhauwaert, P.; Porcile, A. Hormonal contraception and risk of breast cancer: A critical look. Gynecol. Endocrinol. 2019, 35, 460-462. [CrossRef]

191. Nichols, H.B.; Schoemaker, M.J.; Cai, J.; Xu, J.; Wright, L.B.; Brook, M.N.; Jones, M.E.; Adami, H.O.; Baglietto, L.; Bertrand, K.A.; et al. Breast Cancer Risk after Recent Childbirth: A Pooled Analysis of 15 Prospective Studies. Ann. Intern. Med. 2019, 170, 22-30. [CrossRef]

192. Albrektsen, G.; Heuch, I.; Hansen, S.; Kvåle, G. Breast cancer risk by age at birth, time since birth and time intervals between births: Exploring interaction effects. Br. J. Cancer 2005, 92, 167-175. [CrossRef]

193. Executive, H.S. Health and Wellbeing. Available online: https://www.hse.ie/eng/about/who/healthwellbeing/our-priorityprogrammes/heal/key-facts / (accessed on 12 August 2021).

194. Cancer Research UK. Overweight and Obesity Statistics. Available online: https://www.cancerresearchuk.org/healthprofessional/cancer-statistics/risk/overweight-and-obesity (accessed on 12 August 2021).

195. Flegal, K.M.; Carroll, M.D.; Kit, B.K.; Ogden, C.L. Prevalence of Obesity and Trends in the Distribution of Body Mass Index Among US Adults, 1999-2010. JAMA 2012, 307, 491-497. [CrossRef] [PubMed]

196. Wormser, D.; Kaptoge, S.; Di Angelantonio, E.; Wood, A.M.; Pennells, L.; Thompson, A.; Sarwar, N.; Kizer, J.R.; Lawlor, D.A.; Nordestgaard, B.G.; et al. Separate and combined associations of body-mass index and abdominal adiposity with cardiovascular disease: Collaborative analysis of 58 prospective studies. Lancet 2011, 377, 1085-1095.

197. Iyengar, N.M.; Hudis, C.A.; Dannenberg, A.J. Obesity and inflammation: New insights into breast cancer development and progression. Am. Soc. Clin. Oncol. Educ. Book 2013, 33, 46-51. [CrossRef] [PubMed]

198. Renehan, A.G.; Tyson, M.; Egger, M.; Heller, R.; Zwahlen, M. Body-mass index and incidence of cancer: A systematic review and meta-analysis of prospective observational studies. Lancet 2008, 371, 569-578. [CrossRef]

199. Neuhouser, M.L.; Aragaki, A.K.; Prentice, R.L.; Manson, J.E.; Chlebowski, R.; Carty, C.L.; Ochs-Balcom, H.M.; Thomson, C.A.; Caan, B.J.; Tinker, L.F.; et al. Overweight, Obesity, and Postmenopausal Invasive Breast Cancer Risk: A Secondary Analysis of the Women's Health Initiative Randomized Clinical Trials. JAMA Oncol. 2015, 1, 611-621. [CrossRef]

200. Michels, K.B.; Terry, K.L.; Willett, W.C. Longitudinal Study on the Role of Body Size in Premenopausal Breast Cancer. Arch. Intern. Med. 2006, 166, 2395-2402. [CrossRef]

201. Nelson, H.D.; Zakher, B.; Cantor, A.; Fu, R.; Griffin, J.; O’Meara, E.S.; Buist, D.S.; Kerlikowske, K.; van Ravesteyn, N.T.; TrenthamDietz, A.; et al. Risk factors for breast cancer for women aged 40 to 49 years: A systematic review and meta-analysis. Ann. Intern. Med. 2012, 156, 635-648. [CrossRef] [PubMed]

202. Schoemaker, M.J.; Nichols, H.B.; Wright, L.B.; Brook, M.N.; Jones, M.E.; O’Brien, K.M.; Adami, H.O.; Baglietto, L.; Bernstein, L.; Bertrand, K.A.; et al. Association of Body Mass Index and Age with Subsequent Breast Cancer Risk in Premenopausal Women. JAMA Oncol. 2018, 4, e181771. [CrossRef]

203. Lauby-Secretan, B.; Scoccianti, C.; Loomis, D.; Grosse, Y.; Bianchini, F.; Straif, K. Body Fatness and Cancer-Viewpoint of the IARC Working Group. N. Engl. J. Med. 2016, 375, 794-798. [CrossRef] 
204. Protani, M.; Coory, M.; Martin, J. Effect of obesity on survival of women with breast cancer: Systematic review and meta-analysis. Breast Cancer Res. Treat. 2010, 123, 627-635. [CrossRef]

205. Hauner, D.; Janni, W.; Rack, B.; Hauner, H. The Effect of Overweight and Nutrition on Prognosis in Breast Cancer. Dtsch. Ärzteblatt Int. 2011, 108, 795-801. [CrossRef]

206. Chan, D.S.M.; Vieira, A.R.; Aune, D.; Bandera, E.V.; Greenwood, D.C.; McTiernan, A.; Rosenblatt, D.N.; Thune, I.; Vieira, R.; Norat, T. Body mass index and survival in women with breast cancer-Systematic literature review and meta-analysis of 82 follow-up studies. Ann. Oncol. 2014, 25, 1901-1914. [CrossRef]

207. Ramírez, K.; Acevedo, F.; Herrera, M.E.; Ibáñez, C.; Sánchez, C. Physical activity and breast cancer. Rev. Med. Chil. 2017, 145, 75-84. [CrossRef] [PubMed]

208. Ligibel, J.A.; Basen-Engquist, K.; Bea, J.W. Weight Management and Physical Activity for Breast Cancer Prevention and Control. Am. Soc. Clin. Oncol. Educ. Book 2019, 39, e22-e33. [CrossRef] [PubMed]

209. Ligibel, J.A.; Campbell, N.; Partridge, A.; Chen, W.Y.; Salinardi, T.; Chen, H.; Adloff, K.; Keshaviah, A.; Winer, E.P. Impact of a Mixed Strength and Endurance Exercise Intervention on Insulin Levels in Breast Cancer Survivors. J. Clin. Oncol. 2008, 26, 907-912. [CrossRef] [PubMed]

210. Maruti, S.S.; Willett, W.C.; Feskanich, D.; Rosner, B.; Colditz, G.A. A Prospective Study of Age-Specific Physical Activity and Premenopausal Breast Cancer. J. Natl. Cancer Inst. 2008, 100, 728-737. [CrossRef]

211. Thune, I.; Brenn, T.; Lund, E.; Gaard, M. Physical Activity and the Risk of Breast Cancer. N. Engl. J. Med. 1997, 336, 1269-1275. [CrossRef]

212. Hardefeldt, P.J.; Penninkilampi, R.; Edirimanne, S.; Eslick, G.D. Physical Activity and Weight Loss Reduce the Risk of Breast Cancer: A Meta-analysis of 139 Prospective and Retrospective Studies. Clin. Breast Cancer 2018, 18, e601-e612. [CrossRef]

213. McTiernan, A.; Kooperberg, C.; White, E.; Wilcox, S.; Coates, R.; Adams-Campbell, L.L.; Woods, N.; Ockene, J. Recreational Physical Activity and the Risk of Breast Cancer in Postmenopausal Women: The Women's Health Initiative Cohort Study. JAMA 2004, 59, 203-204. [CrossRef] [PubMed]

214. Kehm, R.D.; Genkinger, J.M.; MacInnis, R.J.; John, E.M.; Phillips, K.-A.; Dite, G.S.; Milne, R.L.; Zeinomar, N.; Liao, Y.; Knight, J.A.; et al. Recreational Physical Activity Is Associated with Reduced Breast Cancer Risk in Adult Women at High Risk for Breast Cancer: A Cohort Study of Women Selected for Familial and Genetic Risk. Cancer Res. 2020, 80, 116-125. [CrossRef] [PubMed]

215. Pizot, C.; Boniol, M.; Mullie, P.; Koechlin, A.; Boniol, M.; Boyle, P.; Autier, P. Physical activity, hormone replacement therapy and breast cancer risk: A meta-analysis of prospective studies. Eur. J. Cancer 2016, 52, 138-154. [CrossRef]

216. Neilson, H.K.; Conroy, S.M.; Friedenreich, C.M. The Influence of Energetic Factors on Biomarkers of Postmenopausal Breast Cancer Risk. Curr. Nutr. Rep. 2014, 3, 22-34. [CrossRef] [PubMed]

217. World Cancer Research Fund. Diet, Nutrition, Physical Activity and Cancer: A Global Perspective. Continuous Update Project Expert Report 2018. Available online: www.dietandcancerreport.org (accessed on 18 August 2021).

218. Fairey, A.S.; Courneya, K.S.; Field, C.J.; Bell, G.J.; Jones, L.W.; Mackey, J.R. Effects of exercise training on fasting insulin, insulin resistance, insulin-like growth factors, and insulin-like growth factor binding proteins in postmenopausal breast cancer survivors: A randomized controlled trial. Cancer Epidemiol. Biomark. Prev. 2003, 12, 721-727.

219. Irwin, M.L.; Varma, K.; Alvarez-Reeves, M.; Cadmus, L.; Wiley, A.; Chung, G.G.; DiPietro, L.; Mayne, S.T.; Yu, H. Randomized Controlled Trial of Aerobic Exercise on Insulin and Insulin-like Growth Factors in Breast Cancer Survivors: The Yale Exercise and Survivorship Study. Cancer Epidemiol. Biomark. Prev. 2009, 18, 306-313. [CrossRef]

220. Toledo, E.; Salas-Salvadó, J.; Donat-Vargas, C.; Buil-Cosiales, P.; Estruch, R.; Ros, E.; Corella, D.; Fitó, M.; Hu, F.B.; Arós, F.; et al. Mediterranean Diet and Invasive Breast Cancer Risk among Women at High Cardiovascular Risk in the PREDIMED Trial: A Randomized Clinical Trial. JAMA Intern. Med. 2015, 175, 1752-1760. [CrossRef]

221. Fung, T.T.; Hu, F.B.; McCullough, M.L.; Newby, P.K.; Willett, W.C.; Holmes, M.D. Diet Quality Is Associated with the Risk of Estrogen Receptor-Negative Breast Cancer in Postmenopausal Women. J. Nutr. 2006, 136, 466-472. [CrossRef]

222. Brandt, P.A.V.D.; Schulpen, M. Mediterranean diet adherence and risk of postmenopausal breast cancer: Results of a cohort study and meta-analysis. Int. J. Cancer 2017, 140, 2220-2231. [CrossRef] [PubMed]

223. Du, M.; Liu, S.H.; Mitchell, C.; Fung, T.T. Associations between Diet Quality Scores and Risk of Postmenopausal Estrogen Receptor-Negative Breast Cancer: A Systematic Review. J. Nutr. 2018, 148, 100-108. [CrossRef]

224. Brennan, S.F.; Cantwell, M.M.; Cardwell, C.; Velentzis, L.S.; Woodside, J. Dietary patterns and breast cancer risk: A systematic review and meta-analysis. Am. J. Clin. Nutr. 2010, 91, 1294-1302. [CrossRef]

225. Chlebowski, R.T.; Aragaki, A.K.; Anderson, G.L.; Pan, K.; Neuhouser, M.L.; Manson, J.E.; Thomson, C.A.; Mossavar-Rahmani, Y.; Lane, D.S.; Johnson, K.C.; et al. Dietary Modification and Breast Cancer Mortality: Long-Term Follow-Up of the Women's Health Initiative Randomized Trial. J. Clin. Oncol. 2020, 38, 1419-1428. [CrossRef]

226. Farvid, M.S.; Chen, W.Y.; Michels, K.B.; Cho, E.; Willett, W.C.; Eliassen, A.H. Fruit and vegetable consumption in adolescence and early adulthood and risk of breast cancer: Population based cohort study. BMJ 2016, 353, i2343. [CrossRef] [PubMed]

227. Thiébaut, A.C.M.; Kipnis, V.; Chang, S.-C.; Subar, A.F.; Thompson, F.E.; Rosenberg, P.; Hollenbeck, A.R.; Leitzmann, M.; Schatzkin, A. Dietary Fat and Postmenopausal Invasive Breast Cancer in the National Institutes of Health-AARP Diet and Health Study Cohort. J. Natl. Cancer Inst. 2007, 99, 451-462. [CrossRef] [PubMed]

228. Alexander, D.D.; Morimoto, L.M.; Mink, P.J.; Lowe, K.A. Summary and meta-analysis of prospective studies of animal fat intake and breast cancer. Nutr. Res. Rev. 2010, 23, 169-179. [CrossRef] 
229. Chlebowski, R.T.; Aragaki, A.K.; Anderson, G.L.; Simon, M.S.; Manson, J.E.; Neuhouser, M.L.; Pan, K.; Stefanic, M.L.; Rohan, T.E.; Lane, D.; et al. Association of Low-Fat Dietary Pattern with Breast Cancer Overall Survival: A Secondary Analysis of the Women's Health Initiative Randomized Clinical Trial. JAMA Oncol. 2018, 4, e181212. [CrossRef]

230. Brennan, S.F.; Woodside, J.; Lunny, P.M.; Cardwell, C.; Cantwell, M.M. Dietary fat and breast cancer mortality: A systematic review and meta-analysis. Crit. Rev. Food Sci. Nutr. 2015, 57, 1999-2008. [CrossRef] [PubMed]

231. Barnes, S. 2Phytoestrogens and breast cancer. Baillière's Clin. Endocrinol. Metab. 1998, 12, 559-579. [CrossRef]

232. Messina, M. Impact of Soy Foods on the Development of Breast Cancer and the Prognosis of Breast Cancer Patients. Complement. Med. Res. 2016, 23, 75-80. [CrossRef] [PubMed]

233. Chen, M.; Rao, Y.; Zheng, Y.; Wei, S.; Li, Y.; Guo, T.; Yin, P. Association between Soy Isoflavone Intake and Breast Cancer Risk for Pre- and Post-Menopausal Women: A Meta-Analysis of Epidemiological Studies. PLoS ONE 2014, 9, e89288. [CrossRef] [PubMed]

234. Wei, Y.; The China Kadoorie Biobank Collaborative Group; Lv, J.; Guo, Y.; Bian, Z.; Gao, M.; Du, H.; Yang, L.; Chen, Y.; Zhang, X.; et al. Soy intake and breast cancer risk: A prospective study of 300,000 Chinese women and a dose-response meta-analysis. Eur. J. Epidemiol. 2020, 35, 567-578. [CrossRef]

235. Qiu, S.; Jiang, C. Soy and isoflavones consumption and breast cancer survival and recurrence: A systematic review and meta-analysis. Eur. J. Nutr. 2019, 58, 3079-3090. [CrossRef] [PubMed]

236. Bagnardi, V.; Rota, M.; Botteri, E.; Tramacere, I.; Islami, F.; Fedirko, V.; Scotti, L.; Jenab, M.; Turati, F.; Pasquali, E.; et al. Alcohol consumption and site-specific cancer risk: A comprehensive dose-response meta-analysis. Br. J. Cancer 2015, 112, 580-593. [CrossRef] [PubMed]

237. Cao, Y.; Willett, W.C.; Rimm, E.B.; Stampfer, M.J.; Giovannucci, E.L. Light to moderate intake of alcohol, drinking patterns, and risk of cancer: Results from two prospective US cohort studies. BMJ 2015, 351, h4238. [CrossRef]

238. Allen, N.E.; Beral, V.; Casabonne, D.; Kan, S.W.; Reeves, G.K.; Brown, A.; Green, J. Moderate Alcohol Intake and Cancer Incidence in Women. J. Natl. Cancer Inst. 2009, 101, 296-305. [CrossRef]

239. Singletary, K.W.; Gapstur, S.M. Alcohol and breast cancer: Review of epidemiologic and experimental evidence and potential mechanisms. JAMA 2001, 286, 2143-2151. [CrossRef] [PubMed]

240. Bagnardi, V.; Rota, M.; Botteri, E.; Tramacere, I.; Islami, F.; Fedirko, V.; Scotti, L.; Jenab, M.; Turati, F.; Pasquali, E.; et al. Light alcohol drinking and cancer: A meta-analysis. Ann. Oncol. 2013, 24, 301-308. [CrossRef] [PubMed]

241. Zhang, S.M.; Lee, I.M.; Manson, J.E.; Cook, N.R.; Willett, W.C.; Buring, J.E. Alcohol consumption and breast cancer risk in the Women's Health Study. Am. J. Epidemiol. 2007, 165, 667-676. [CrossRef] [PubMed]

242. Hirko, K.; Chen, W.Y.; Willett, W.C.; Rosner, B.A.; Hankinson, S.E.; Beck, A.H.; Tamimi, R.M.; Eliassen, A.H. Alcohol consumption and risk of breast cancer by molecular subtype: Prospective analysis of the nurses' health study after 26 years of follow-up. Int. J. Cancer 2016, 138, 1094-1101. [CrossRef] [PubMed]

243. Chen, W.Y.; Rosner, B.; Hankinson, S.E.; Colditz, G.; Willett, W.C. Moderate Alcohol Consumption during Adult Life, Drinking Patterns, and Breast Cancer Risk. JAMA 2011, 306, 1884-1890. [CrossRef] [PubMed]

244. White, A.J.; DeRoo, L.A.; Weinberg, C.; Sandler, D.P. Lifetime Alcohol Intake, Binge Drinking Behaviors, and Breast Cancer Risk. Am. J. Epidemiol. 2017, 186, 541-549. [CrossRef]

245. Tseng, M.; Weinberg, C.R.; Umbach, D.M.; Longnecker, M.P. Calculation of population attributable risk for alcohol and breast cancer (United States). Cancer Causes Control. 1999, 10, 119-123. [CrossRef]

246. Schütze, M.; Boeing, H.; Pischon, T.; Rehm, J.; Kehoe, T.; Gmel, G.; Olsen, A.; Tjonneland, A.; Dahm, C.; Overvad, K.; et al. Alcohol attributable burden of incidence of cancer in eight European countries based on results from prospective cohort study. BMJ 2011, 342, d1584. [CrossRef]

247. Laffoy, M.; McCarthy, T.; Mullen, L.; Byrne, D.; Martin, J. Cancer incidence and mortality due to alcohol: An analysis of 10-year data. Ir. Med. J. 2013, 106, 294-297.

248. De Bruin, M.L.; Sparidans, J.; van't Veer, M.B.; Noordijk, E.M.; Louwman, M.W.; Zijlstra, J.M.; van den Berg, H.; Russell, N.S.; Broeks, A.; Baaijens, M.H.; et al. Breast cancer risk in female survivors of Hodgkin's lymphoma: Lower risk after smaller radiation volumes. J. Clin. Oncol. 2009, 27, 4239-4246. [CrossRef]

249. Swerdlow, A.J.; Cooke, R.; Bates, A.; Cunningham, D.; Falk, S.J.; Gilson, D.; Hancock, B.W.; Harris, S.J.; Horwich, A.; Hoskin, P.J.; et al. Breast cancer risk after supradiaphragmatic radiotherapy for Hodgkin's lymphoma in England and Wales: A National Cohort Study. J. Clin. Oncol. 2012, 30, 2745-2752. [CrossRef]

250. McGregor, H.; Land, C.E.; Choi, K.; Tokuoka, S.; Liu, P.I.; Wakabayashi, T.; Beebe, G.W. Breast cancer incidence among atomic bomb survivors, Hiroshima and Nagasaki, 1950-1969. J. Natl. Cancer Inst. 1977, 59, 799-811. [CrossRef]

251. Carmichael, A.; Sami, A.; Dixon, J. Breast cancer risk among the survivors of atomic bomb and patients exposed to therapeutic ionising radiation. Eur. J. Surg. Oncol. 2003, 29, 475-479. [CrossRef]

252. Miglioretti, D.L.; Lange, J.; van den Broek, J.J.; Lee, C.I.; van Ravesteyn, N.T.; Ritley, D.; Kerlikowske, K.; Fenton, J.J.; Melnikow, J.; de Koning, H.J.; et al. Radiation-Induced Breast Cancer Incidence and Mortality from Digital Mammography Screening: A Modeling Study. Ann. Intern. Med. 2016, 164, 205-214. [CrossRef] [PubMed]

253. Odle, T.G. Radiation Dose in Breast Imaging. Radiol. Technol. 2018, 89, 371M-390M. [PubMed]

254. Berrington de Gonzalez, A.; Berg, C.D.; Visvanathan, K.; Robson, M. Estimated risk of radiation-induced breast cancer from mammographic screening for young BRCA mutation carriers. J. Natl. Cancer Inst. 2009, 101, 205-209. [CrossRef] [PubMed] 
255. Greuter, M.J.; Der Weide, M.C.J.-V.; Jacobi, C.E.; Oosterwijk, J.C.; Jansen, L.; Oudkerk, M.; De Bock, G.H. The validation of a simulation model incorporating radiation risk for mammography breast cancer screening in women with a hereditary-increased breast cancer risk. Eur. J. Cancer 2010, 46, 495-504. [CrossRef] [PubMed]

256. Lowry, K.P.; Lee, J.M.; Kong, C.Y.; McMahon, P.M.; Gilmore, M.E.; Cott Chubiz, J.E.; Pisano, E.D.; Gatsonis, C.; Ryan, P.D.; Ozanne, E.M.; et al. Annual screening strategies in BRCA1 and BRCA2 gene mutation carriers: A comparative effectiveness analysis. Cancer 2012, 118, 2021-2030. [CrossRef]

257. De Blok, C.J.M.; Wiepjes, C.M.; Nota, N.M.; van Engelen, K.; Adank, M.A.; Dreijerink, K.M.A.; Barbé, E.; Konings, I.; den Heijer, $\mathrm{M}$. Breast cancer risk in transgender people receiving hormone treatment: Nationwide cohort study in the Netherlands. BMJ 2019, 365, 11652. [CrossRef] [PubMed]

258. Clarke, C.N.; Cortina, C.S.; Fayanju, O.M.; Dossett, L.A.; Johnston, F.M.; Wong, S.L. Breast Cancer Risk and Screening in Transgender Persons: A Call for Inclusive Care. Ann. Surg. Oncol. 2021, 1-5. [CrossRef]

259. Shao, T.; Grossbard, M.L.; Klein, P. Breast Cancer in Female-to-Male Transsexuals: Two Cases with a Review of Physiology and Management. Clin. Breast Cancer 2011, 11, 417-419. [CrossRef]

260. Katayama, Y.; Motoki, T.; Watanabe, S.; Miho, S.; Kimata, Y.; Matsuoka, J.; Doihara, H.; Nanba, Y. A very rare case of breast cancer in a female-to-male transsexual. Breast Cancer 2015, 23, 939-944. [CrossRef]

261. Gooren, L.; Bowers, M.; Lips, P.; Konings, I.R. Five new cases of breast cancer in transsexual persons. Andrologia 2015, 47, 1202-1205. [CrossRef]

262. Nikolic, D.V.; Djordjevic, M.L.; Granic, M.; Nikolic, A.T.; Stanimirovic, V.V.; Zdravkovic, D.; Jelic, S. Importance of revealing a rare case of breast cancer in a female to male transsexual after bilateral mastectomy. World J. Surg. Oncol. 2012, 10, 280. [CrossRef]

263. Burcombe, R.; Makris, A.; Pittam, M.; Finer, N. Breast cancer after bilateral subcutaneous mastectomy in a female-to-male trans-sexual. Breast 2003, 12, 290-293. [CrossRef]

264. McCarthy, M.; Birney, E. Personalized profiles for disease risk must capture all facets of health. Nature 2021, 597, 175-177. [CrossRef]

265. Evans, D.G.R.; Howell, A. Breast cancer risk-assessment models. Breast Cancer Res. 2007, 9, 213. [CrossRef] [PubMed]

266. Gail, M.H.; Brinton, L.A.; Byar, D.P.; Corle, D.K.; Green, S.B.; Schairer, C.; Mulvihill, J.J. Projecting Individualized Probabilities of Developing Breast Cancer for White Females Who Are Being Examined Annually. J. Natl. Cancer Inst. 1989, 81, 1879-1886. [CrossRef] [PubMed]

267. Claus, E.B.; Risch, N.; Thompson, W.D. Genetic analysis of breast cancer in the cancer and steroid hormone study. Am. J. Hum. Genet. 1991, 48, 232-242. [PubMed]

268. Gail, M.H.; Costantino, J.P.; Pee, D.; Bondy, M.; Newman, L.; Selvan, M.; Anderson, G.L.; Malone, K.E.; Marchbanks, P.A.; McCaskill-Stevens, W.; et al. Projecting Individualized Absolute Invasive Breast Cancer Risk in African American Women. J. Natl. Cancer Inst. 2007, 99, 1782-1792. [CrossRef] [PubMed]

269. Matsuno, R.K.; Costantino, J.P.; Ziegler, R.G.; Anderson, G.L.; Li, H.; Pee, D.; Gail, M.H. Projecting Individualized Absolute Invasive Breast Cancer Risk in Asian and Pacific Islander American Women. J. Natl. Cancer Inst. 2011, 103, 951-961. [CrossRef]

270. Banegas, M.P.; Gail, M.H.; Lacroix, A.; Thompson, B.; Martinez, M.E.; Wactawski-Wende, J.; John, E.M.; Hubbell, F.A.; Yasmeen, S.; Katki, H.A. Evaluating breast cancer risk projections for Hispanic women. Breast Cancer Res. Treat. 2012, 132, 347-353. [CrossRef] [PubMed]

271. Parmigiani, G.; Berry, D.A.; Aguilar, O. Determining Carrier Probabilities for Breast Cancer-Susceptibility Genes BRCA1 and BRCA2. Am. J. Hum. Genet. 1998, 62, 145-158. [CrossRef] [PubMed]

272. Tyrer, J.; Duffy, S.W.; Cuzick, J. A breast cancer prediction model incorporating familial and personal risk factors. Stat. Med. 2004, 23, 1111-1130. [CrossRef]

273. Carver, T.; Hartley, S.; Lee, A.; Cunningham, A.P.; Archer, S.; de Villiers, C.B.; Roberts, J.; Ruston, R.; Walter, F.M.; Tischkowitz, M.; et al. CanRisk Tool-A Web Interface for the Prediction of Breast and Ovarian Cancer Risk and the Likelihood of Carrying Genetic Pathogenic Variants. Cancer Epidemiol. Biomark. Prev. 2021, 30, 469-473. [CrossRef]

274. Cleveland Clinic PTEN Risk Calculator. Available online: www.lerner.ccf.org/gmi/ccscore/ (accessed on 27 September 2021).

275. Rebbeck, T.R.; Friebel, T.M.; Mitra, N.; Wan, F.; Chen, S.; Andrulis, I.L.; Apostolou, P.; Arnold, N.; Arun, B.K.; Barrowdale, D.; et al. Inheritance of deleterious mutations at both BRCA1 and BRCA2 in an international sample of 32,295 women. Breast Cancer Res. 2016, 18, 112. [CrossRef] [PubMed]

276. Rana, H.Q.; Gelman, R.; LaDuca, H.; McFarland, R.; Dalton, E.; Thompson, J.; Speare, V.; Dolinsky, J.S.; Chao, E.C.; Garber, J.E. Differences in TP53 Mutation Carrier Phenotypes Emerge From Panel-Based Testing. J. Natl. Cancer Inst. 2018, 110, 863-870. [CrossRef]

277. Zhu, X.; Wolfgruber, T.K.; Leong, L.; Jensen, M.; Scott, C.; Winham, S.; Sadowski, P.; Vachon, C.; Kerlikowske, K.; Shepherd, J.A. Deep Learning Predicts Interval and Screening-detected Cancer from Screening Mammograms: A Case-Case-Control Study in 6369 Women. Radiology 2021, 203758. [CrossRef]

278. McKinney, S.M.; Sieniek, M.; Godbole, V.; Godwin, J.; Antropova, N.; Ashrafian, H.; Back, T.; Chesus, M.; Corrado, G.S.; Darzi, A.; et al. International evaluation of an AI system for breast cancer screening. Nature 2020, 577, 89-94. [CrossRef] [PubMed]

279. Ming, C.; Viassolo, V.; Probst-Hensch, N.; Dinov, I.D.; Chappuis, P.O.; Katapodi, M.C. Machine learning-based lifetime breast cancer risk reclassification compared with the BOADICEA model: Impact on screening recommendations. Br. J. Cancer 2020, 123, 860-867. [CrossRef] [PubMed] 